\title{
PERFORMANCE OF A BUILDING INTEGRATED PHOTOVOLTAIC/THERMAL (BIPVT)
}

\section{SOLAR COLLECTOR}

\author{
T.N. Anderson ${ }^{1 *}$, M. Duke*, G.L. Morrison ${ }^{+}$, J.K. Carson* \\ *Department of Engineering, \\ University of Waikato, Hamilton, New Zealand, 3240 \\ ${ }^{+}$School of Mechanical and Manufacturing Engineering \\ University of New South Wales, Sydney, Australia, 2052
}

\begin{abstract}
The idea of combining photovoltaic and solar thermal collectors (PVT collectors) to provide electrical and heat energy is an area that has, until recently, received only limited attention. Although PVTs are not as prevalent as solar thermal systems, the integration of photovoltaic and solar thermal collectors into the walls or roofing structure of a building could provide greater opportunity for the use of renewable solar energy technologies. In this study, the design of a novel building integrated photovoltaic/thermal (BIPVT) solar collector was theoretically analysed through the use of a modified Hottel-Whillier model and was validated with experimental data from testing on a prototype BIPVT collector.
\end{abstract}

The results showed that key design parameters such as the fin efficiency, the thermal conductivity between the PV cells and their supporting structure, and the lamination method had a significant influence on both the electrical and thermal efficiency of the BIPVT. Furthermore, it was shown that

\footnotetext{
${ }^{1}$ Corresponding Author: Tel.: +64 78384266 Fax: +64 78384835

E-mail address: timothy.anderson@unswAlumni.com (T.N. Anderson)
} 
the BIPVT could be made of lower cost materials, such as pre-coated colour steel, without significant decreases in efficiency.

Finally, it was shown that by integrating the BIPVT into the building rather than onto the building could result in a lower cost system. This was illustrated by the finding that insulating the rear of the BIPVT may be unnecessary when it is integrated into a roof above an enclosed air filled attic, as this air space acts as a passive insulating barrier.

\section{KEYWORDS:}

Photovoltaics; solar thermal; photovoltaic/thermal; BIPVT

\section{INTRODUCTION}

The utilisation of solar energy has traditionally been divided into two fields; solar thermal and photovoltaics. Solar thermal research is, as the name suggests, concerned with the utilisation of solar radiation to provide useful heating. Typical examples include passive solar heating of houses and solar water heating. Photovoltaics, on the other hand, are concerned with the conversion of solar energy to electricity, mainly through the use of silicon based solar cells.

Solar thermal energy has a long history and is used extensively for water and space heating. A survey by the International Energy Agency Solar Heating and Cooling programme (IEA SHC) (2006) found that, in 2004, there was approximately $141 \times 10^{6} \mathrm{~m}^{2}$ of solar thermal collectors in its 41 member countries. This survey also found that the solar thermal collector market in Australia and New Zealand was growing at a rate of $19 \%$ per annum. Furthermore, it showed that the use of solar thermal energy resulted in significant reductions in the use of energy from other sources. 
In contrast, photovoltaic devices have a much shorter history than solar thermal systems; however they too have received significant attention. Over the last decade, the photovoltaic market has moved away from the traditional application of standalone off-grid power sources to grid connected systems, thus opening the technology to a wider market.

One of the key shortcomings of photovoltaics however is their relatively low efficiency. Typically, commercially available PV modules are only able to convert 6-18\% of the incident radiation falling on them to electrical energy, with the remainder lost by reflection or as heat (Bazilian et. al. 2002). However, a small portion of the heat is "sunk" into the cells which results in a reduction in their efficiency.

Green (1998) notes that the short circuit current of PV cells is not strongly temperature dependent; however it tends to increase slightly due to increased light absorption. This he attributes to the temperature dependant decrease in band gap in the semiconductor materials used in the cells.

Moreover, using a simple diode model Green shows that the relationship between the short circuit current $\left(I_{s c}\right)$ and open circuit voltage $\left(V_{o c}\right)$ given in Equation 1 can be reduced to an expression for the change in open circuit voltage with respect to temperature (T), Equation 2, where $I_{0}$ is the diode saturation current, $k$ is the Boltzmann constant, $q$ is the element charge and $\gamma$ is a parameter used to accommodate other temperature dependencies. This he notes leads to a decrease in efficiency of approximately $0.5 \% /{ }^{\circ} \mathrm{C}$ for typical silicon based PV cells.

$$
\begin{array}{r}
I_{S C}=I_{0}\left(e^{q V_{o c} / k T}-1\right) \\
\frac{d V_{o c}}{d T}=-\frac{V_{g 0}-V_{o c}+\gamma\left(\frac{k T}{q}\right)}{T}
\end{array}
$$


In order to reduce the impact of temperature on PV cell performance, a cooling system can be implemented to take heat out of them. However rather than just dumping this heat to the environment, it is possible to capture and store it. As such, a number of studies in the late 1970's, began to investigate the use of the heat generated by photovoltaics in what have become known as Photovoltaic/Thermal (PVT) solar collectors. These studies were largely shelved during the 1980's however with concern growing over energy sources and their usage PVTs have started receiving more attention.

Van Helden et. al. (2004) noted that PV collectors absorb 80\% of the incident solar radiation but convert only a small portion of this to electrical energy, the remainder being dissipated as thermal energy. Furthermore, they noted that the temperatures reached by PV cells are higher than the ambient temperature and that the efficiency of PVTs is greater than the combined sum of separate PV and thermal collectors. In light of this, they suggest that PVT systems offer a cost effective solution for applications where roof area is limited.

Although not as prevalent as solar thermal systems, Florschuetz (1979) provided perhaps the earliest theoretical analysis of a PVT solar collector through the use of a modified Hottel-Whillier model. Bergene and Lovvik (1995) also conducted a theoretical examination of a flat plate solar collector with integrated solar cells based on the Hottel-Whillier model. They developed a series of algorithms which they utilized in calculating both the thermal and electrical efficiency of a PVT system. They suggested that such systems might be useful as pre-heaters for domestic hot water services.

More recently, Tripanagnostopoulos et. al. (2002) conducted tests on hybrid PVT systems using polycrystalline (pc-Si) and amorphous (a-Si) silicon PV cells. They found that the cooling provide by the thermal integration assisted in improving the efficiency of the PV cells by approximately $10 \%$. Additionally, they found that water cooling provided better cooling than air circulation. Finally, they suggested that the performance of these systems could be further improved through the use of diffuse 
reflectors or through glazing. However, glazing the collectors would improve thermal performance to the detriment of the electrical efficiency.

He et. al. (2006) recently studied a hybrid PVT system which used natural convection to circulate the cooling water. They found that their system showed a combined efficiency in the order of $50 \%$, with the thermal efficiency contributing approximately 40\%. Although they found that the thermal efficiency was less than a conventional thermosyphon solar water heater they note that the energy saving efficiency was greater.

Chow et. al. (2006) also examined the hybrid PVT system of He et. al. (2006) and developed a dynamic thermal model. They suggested that this system could be improved by placing the PV cells on the lower portion of their collector. They noted that there was a larger temperature gradient between the water entering the thermosyphon tubes and the PV cells in this region and so the electrical and thermal efficiency could be improved by placing the cells there.

Many of the systems mentioned however have only focused on stand-alone PVT water heating devices with little integration into buildings. Bazilian et. al. (2001) presents a comprehensive examination of PV and PVT in built environments and highlights the fact that PVT systems are well suited to low temperature applications. Furthermore they note that the integration of PV systems into the built environment can achieve "a cohesive design, construction and energy solution” (p.57). Finally, they note the need for further research to be undertaken before combined PVT systems become a successful commercial reality.

Given the research that has been conducted to date, it is apparent that there is still a large amount of work that needs to be undertaken before PVT systems can be successfully implemented and integrated into domestic and commercial building applications. 


\section{BIPVT OVERVIEW}

The system examined in this study is unique in a number of ways. Unlike many of the systems that have been proposed, this system is directly integrated into the roof of a building, in this case a standing seam or troughed sheet roof. Standing seam and troughed sheet roofs are typically made from aluminium or coated steel, although copper or stainless steel could be used. They are rolled or pressed into a shape that gives the roof product stiffness, strength and when assembled are weather proof. This system utilises the high thermal conductivity materials used in these roofing systems to form the BIPVT collector. During the manufacturing process in addition to the normal troughed shape, passageways are added to the trough for the thermal cooling medium to travel through.

In essence, a cover having PV cells laminated to its surface is bonded into the trough. The passageways formed in the trough are subsequently enclosed by the cover; thus forming a tube to which heat can be transferred. The flow ways have an inlet and outlet at opposite ends of the trough as shown in Figure 1. In addition the design allows a glass or polymer glazing to be added to the collector to create an air gap between the outer surface of the PV module and laminate surface and the ambient air. This could be used to increase the temperature of the BIPVT to improve the thermal efficiency of the collector. 
As the PV cells are exposed to sunlight they absorb radiation and generate electricity, however, silicon PV cells tend to convert only short wavelength radiation to electricity while the longer wavelengths result in heating of the laminate. As such, in the BIPVT collector there is heat transfer from the cells through the laminate to the fluid passing underneath. The fluid is pumped along the flow paths and output through a manifold and pipes and fed to a heat exchanger that removes the heat from the fluid. The heating of the fluid reduces the temperature of the PV cells, thereby increasing their efficiency under high temperature and radiation conditions.

\section{METHODOLOGY}

In order to analyse the thermal and electrical performance of the BIPVT a one dimensional steady state thermal model was developed with the collector could be represented as a flat plate thermal collector. As such a modified from of the Hottel-Whillier-Bliss equations presented by Duffie and Beckman (2006) were used.

Under these conditions the useful heat gain can be calculated using Equation 3.

$$
Q=A F_{R}\left[(\tau \alpha)_{P V} \cdot G-U_{\text {loss }}\left(T_{I}-T_{a}\right)\right]
$$

In this equation the useful heat gain $(Q)$ is represented by a function of the collector area $(A)$, the heat removal efficiency factor $\left(F_{R}\right)$, the transmittance-absorptance product of the photovoltaic cells $\left(\tau \alpha_{P V}\right)$, the solar radiation $(G)$, the collector heat loss coefficient $\left(U_{\text {loss }}\right)$ and the temperature difference between the cooling medium inlet temperature $\left(T_{i}\right)$ and the ambient temperature $\left(T_{a}\right)$.

Furthermore, the heat removal efficiency factor $\left(F_{R}\right)$ can be calculated using Equation 4, which also accounts for the mass flow rate in the collector $(m)$ and the specific heat of the collector cooling medium $\left(C_{p}\right)$. 


$$
F_{R}=\frac{m C_{P}}{A U_{\text {loss }}}\left[1-e^{-\frac{A U_{\text {loss }} F^{\prime}}{m C_{P}}}\right]
$$

In order to obtain the heat removal efficiency factor however, it is necessary to calculate a value for the corrected fin efficiency $\left(F^{\prime}\right)$. This is done by first calculating the fin efficiency $(F)$ using Equation 5.

$$
F=\frac{\tanh \left(M \frac{W-d}{2}\right)}{\left(M \frac{W-d}{2}\right)}
$$

This equation determines the efficiency of the finned area between adjacent tubes by taking into account the influence of the tube pitch $(W)$ and the tube width $(d)$ of the rectangular cross-section tubes formed in the fabrication of the BIPVT. As such all calculations related to flow in the tubes were based on the tubes hydraulic diameter $\left(d_{h}\right)$.

The coefficient $(M)$ is a term which accounts for the thermal conductivity of the absorber and PV cell and is represented by Equation 6 (Vokas et. al. 2006).

$$
M=\sqrt{\frac{U_{\text {loss }}}{k_{a b s} L_{a b s}+k_{P V} L_{P V}}}
$$

As such, the corrected fin efficiency $\left(F^{\prime}\right)$ can be calculated using Equation 7.

$$
F^{\prime}=\frac{\frac{1}{U_{\text {loss }}}}{W\left[\frac{1}{U_{\text {loss }}(d+(W-d) F}\right]+\frac{1}{W h_{P V A}}+\frac{1}{\pi d h_{\text {fluid }}}}
$$


Now in Equation $7, h_{P V A}$ is a "quasi" heat transfer coefficient to account for the bond resistance between the PV cell and the absorber (Zondag et. al., 2002) and $h_{\text {fluid }}$ is the forced convection heat transfer coefficient inside the cooling passage determined from the Dittus-Boulter equation. Furthermore, the overall heat loss coefficient $\left(U_{\text {loss }}\right)$ of the collector represents the summation of the collector edge (Equation 8, where $p$ is the collector perimeter and $t$ is the absorber thickness), top and rear surface losses. In this equation it was assumed that the top loss coefficient, due to wind, could be calculated using Klein’s empirical equation (Equation 9) as given by Duffie and Beckman (2006).

$$
\begin{gathered}
U_{\text {edge }}=\frac{k_{\text {edge }} p t}{L_{\text {edge }} A_{\text {collector }}} \\
U_{\text {top }}=\left\{\begin{array}{c}
\left.\frac{N}{\frac{c}{T_{p m}}\left(\frac{T_{p m}-T_{a}}{N-f}\right)^{e}}+\frac{1}{h_{w}}\right\}^{-1}+\frac{\sigma\left(T_{p m}+T_{a}\right)\left(T_{p m}^{2}+T_{a}^{2}\right)}{\left(\varepsilon_{p}+0.00591 N h_{w}\right)^{-1}+\frac{2 N+f-1+0.133 \varepsilon_{p}}{\varepsilon_{g}}-N}
\end{array}\right.
\end{gathered}
$$

Where:

$$
\begin{array}{cc}
c=\left(520-0.000051 \beta^{2}\right) & f=\left(1+0.089 h_{w}-0.1166 h_{w} \varepsilon_{p}\right)(1+0.07866 N) \\
e=0.430\left(1-\frac{100}{T_{p m}}\right) & T_{p m}=T_{i}+\frac{Q / A_{\text {collector }}}{F_{R} U_{\text {loss }}}\left(1-F_{R}\right)
\end{array}
$$

$\beta$ is the collector mounting, $\sigma$ is the Stefan-Boltzmann constant, $N$ is the number of covers or glazing layers, $\varepsilon_{g}$ the emittance of the cover or glazing, $\varepsilon_{p}$ the emittance of the plate and $h_{w}$ is the convection heat transfer due to the wind and is discussed later in this work.

However, if we consider the case of an unglazed collector, in which there is no cover, Equation 9 can not be applied. Instead it is necessary to calculate the top loss coefficient $\left(U_{\text {top }}\right)$ by taking the summation of the individual contributions of radiation, natural and forced convection. 
Under such conditions, the heat loss due to radiation can be expressed as a radiation heat transfer coefficient in terms of the sky temperature $\left(T_{s}\right)$, the mean collector plate temperature $\left(T_{p m}\right)$ and the plate emissivity $\left(\varepsilon_{p}\right)$ as shown in Equation 10 (Eicker, 2003).

$$
h_{r}=\sigma \varepsilon_{p}\left(T_{p m}^{2}+T_{s}^{2}\right)\left(T_{p m}+T_{s}\right)
$$

where the sky temperature is represented by the modified Swinbank equation of Fuentes (1987) as a function of the ambient temperature as shown in Equation 11.

$$
T_{s}=0.037536 T_{a}^{1.5}+0.32 T_{a}
$$

Furthermore, the losses due to natural and forced convection must also be taken into account. The forced convection heat transfer coefficient $\left(h_{w}\right)$ can be calculated using Watmuff et. al.' (1977) correlation in terms of wind velocity (v), as shown in Equation 12, while the natural convection loss $\left(h_{\text {nat }}\right)$ can be represented by a function of the temperature difference between the mean collector plate temperature $\left(T_{p m}\right)$ and the ambient temperature $\left(T_{a}\right)$ as shown in Equation 13 (Eicker, 2003).

$$
\begin{aligned}
& h_{w}=2.8+3.0 v \\
& h_{\text {nat }}=1.78\left(T_{p m}-T_{a}\right)^{1 / 3}
\end{aligned}
$$

Using this method it is possible to determine an overall convection heat transfer coefficient $\left(h_{c}\right)$ by combining both forced and natural convection heat transfer as shown in Equation 14 (Eicker, 2003). Subsequently by taking the summation of the convection and radiation losses, it is possible to determine the overall top loss heat transfer coefficient $\left(U_{\text {top }}\right)$ for the unglazed collector.

$$
h_{c}=\sqrt[3]{h_{w}^{3}+h_{\text {nat }}^{3}}
$$


Now, typically, when analysing solar thermal and standalone PVT collector systems, the rear surface heat loss coefficient is given by the inverse of the insulation R-value (ie. $k_{b} / L_{b}$ ); however it should be recognised that, ideally, the BIPVT will be integrated into the building rather than merely onto the building. As such, if the collector is integrated into the roof of a building then the calculation of the heat loss through the bottom or rear surface is less straight forward.

Given that the collector would be integrated into a roof it is feasible that it may be installed on a building using a "cold roof” insulation system. In such an installation the building would be insulated at ceiling level, therefore the use of insulation at the rear surface of the BIPVT would represent a second layer of insulation thereby adding to the cost of the system. Now in this mode of operation, it was recognised that the BIPVT would be installed above the air filled attic and that air had a similar thermal conductivity to typical insulation materials therefore presenting the possibility of using the air in this space as an insulating layer. Therefore the correlation for free convection in a triangular enclosure, or a pitched roof attic space, developed by Ridouane and Campo (2005) (Equation 15) was used to determine the heat loss from the rear surface of the BIPVT.

$$
N u=0.286 A^{-0.286} G r^{1 / 4}
$$

Where $A$ is the aspect ratio of the attic or enclosure and is the ratio of the vertical height $(H)$ and the horizontal width. The Grashof number $(G r)$ was taken to be given by Equation 16 with properties based on the average of the BIPVT mean temperature and the ambient temperature:

$$
G r=\frac{g \beta\left(T_{p m}-T_{a}\right) H^{3}}{v^{2}}
$$


Based on this, it is possible to calculate the heat transfer coefficient due to natural convection along the rear of the BIPVT collector and subsequently the overall heat loss coefficient for Equation 7.

Additionally, it is possible to analyse the thermal performance of the BIPVT collector by the inclusion of a packing factor. In practical terms, it is not always possible to have complete coverage of a panel with photovoltaic cells. As such Equation 3 can be modified to account for this packing factor $(S)$ and the transmittance-absorptance product of the collector material $\left(\tau \alpha_{T}\right)$ on to which the PV cells are laminated, as shown in Equation 17.

$$
Q=S\left[A F_{R}\left[\tau \alpha_{P V} \cdot G-U_{\text {loss }}\left(T_{I}-T_{a}\right)\right]\right]+(1-S)\left[A F_{R}\left[\tau \alpha_{T} \cdot G-U_{\text {loss }}\left(T_{I}-T_{a}\right)\right]\right]
$$

From these equations it is then possible to calculate the useful heat gain by the solar collector and the mean temperature of the BIPVT $\left(T_{p m}\right)$. The electrical efficiency can be calculated based on the difference between the mean temperature of the BIPVT and the Nominal Operating Cell Temperature (NOCT), which is typically taken as $298 \mathrm{~K}$. For this study it was assumed that the cell had an efficiency of 15\% (typical of a crystalline silicon PV cell) at NOCT, and that the temperature dependent efficiency could be represented by Equation 18; where it was also assumed a $0.5 \% /{ }^{\circ} \mathrm{C}$ decrease in electrical efficiency would occur (Green, 1998).

$$
\eta_{\text {electrical }}=0.15\left(1-0.005\left(T_{p m}-N O C T\right)\right)
$$

Furthermore, by rearranging Equation 3 or 17, we can develop an equation for determining the thermal efficiency of the BIPVT, based on the transmittance-absorptance product of the BIPVT accounting for the packing factor. This equation is then expressed in the form shown in Equation 19.

$$
\eta_{\text {thermal }}=F_{R}\left(\left(S \times \tau \alpha_{P V}\right)+(1-S) \times \tau \alpha_{T}\right)-F_{R} U_{\text {loss }} \frac{T_{I}-T_{a}}{G}
$$


As such, by combining the elements of this design model and methodology it is therefore possible to predict the performance of a BIPVT style collector.

\section{EXPERIMENTAL TESTING AND MODEL VALIDATION}

In the previous section the design methodology for the BIPVT was discussed and a number of parameters influencing its efficiency were identified. However, in order for the outcomes of the design methodology to be satisfactorily proven, it was necessary to validate the model against experimental data to ensure the validity of the model. To achieve this validation, it was decided to use a steady state outdoor thermal test setup (Figure 2) similar to that recommended in AS/NZS 2535.1 (1999) to determine the efficiency of the BIPVT collector.

Before any testing could be conducted it was necessary to fabricate a prototype BIPVT collector. Although the fabrication of finned copper tube style collectors is well understood, the unconventional design of the BIPVT and some of the desired design goals, in particular that it be made from precoated steel, presented a number of challenges. This is mainly due to the fact that the material is galvanised and dip coated in black paint and so could not be easily welded without removing both these coatings. In order to circumvent this issue, the top absorber sheet to which the PV cells are laminated, was bonded to the supporting troughed roof sheet with a high temperature Silicone adhesive and sealant.

The roof profile was folded using a CNC folder, holes were drilled to allow fluid into the underside of the coolant trough, nipples were TIG welded to the rear surface to allow a manifold to be attached, the ends were sealed with Silicone and the top absorber sheet was glued into place with the same. Once sealed and watertight, PV cells were laminated to the top absorber sheet and encapsulated in a Poly- 
vinyl resin. Finally, the ends of the roof trough profile were enclosed and a low-iron-glass cover was placed over the collector to prevent convection losses.

However, due to the practicalities associated with installing the BIPVT into an actual building roof, the rear surface of the collector panel was instead insulated with $100 \mathrm{~mm}$ of mineral fibre insulation thereby forming a standalone collector but with a roof profile, similar to that seen in Figure 1.

In Table 1 the design parameters of the prototype collector are given, it will be shown later, that the prototype is far from an optimum design. In particular the prototype used a much narrower cooling trough than would be considered ideal, and therefore had a far from optimal tube diameter to spacing ratio. In addition, the encapsulation method was significantly different from that used by previous researchers, with the PV cells covered by a very fine film of resin. This method of encapsulation would not however be suitable for a commercial BIPVT, due to the poor longevity of the resin under high temperature operation. Despite the difference in the lamination method, it was assumed that the transmittance-absorptance product and the "quasi" bond resistance remained unchanged from those suggested by de Vries (1998). A packing factor of $40 \%$ was applied to the collector to test that the method outlined for the determination of thermal efficiency of a BIPVT was valid.

The results shown in Figures 3 and 4 clearly illustrate that the design model is capable of predicting the heat gain of the collector in both a glazed and unglazed configuration with good accuracy. Perhaps most importantly, Figures 5 and 6 show that the model is able to predict the thermal efficiency of the collector extremely well. As such it can be said, that despite being a somewhat simplified representation of a BIPVT collector, the model is more than adequate for use in the design and optimisation of BIPVT style collectors. 


\section{DESIGN RESULTS}

Having established a validated methodology for calculating the performance of BIPVT solar collectors, some typical design values were chosen for a medium to large BIPVT installation, as shown in Table 2, to examine the efficiency of the collector over a range of possible design configurations.

From the characteristics given in Table 2, and the physical testing, it was apparent that a number of variables could be modified in order to improve the thermal efficiency of the BIPVT system. As such a sensitivity analysis was conducted to determine how some of these variables would affect the thermal efficiency of the system relative to the ratio between the reduced temperature $\left(T_{\text {in }}-T_{a}\right)$ and the global radiation incident on the collector surface ( $G$ ”). In this sensitivity study, only a single design parameter was varied from the data given in Table 2 at any one time. This allows us to determine the parameters that have the greatest influence on the BIPVT performance, and to provide an insight into what gains could be made by changing them.

Heat transfer in the fluid channel is controlled by the Reynolds number which is a function of flow rate; as such flow rate was varied to examine its effect on the array thermal efficiency. In Figure 7 it can be seen that it has negligible effect on thermal efficiency, however, the increase in Reynolds number means that heat transfer from the PV cells is improved, thus meaning that electrical efficiency increases marginally.

Furthermore, it may be possible to vary the material from which the collector is made. In Table 2 it was assumed that the collector was made from steel, however, by using aluminium or copper it is possible to increase the thermal conductivity and hence transfer within the panel. However, as shown in Figure 8, the material from which the collector is made does not significantly improve the thermal 
efficiency. This is a surprising result as a solar collector for water heating would typically be constructed of copper to help maximise the fin efficiency, however for the BIPVT system this appears to have negligible impact. As such, it suggests that lower cost materials such as steel could be used in their construction, despite its relatively low thermal conductivity.

One reason for the lack of sensitivity to changes of the thermal absorber plate conductivity presented in Table 2 is the high geometric fin efficiency. As explained previously the fin efficiency is a function of the rectangular tube width $(d)$ used in the BIPVT and the spacing between adjacent tubes $(W)$. For the results shown in Figure 8, it was assumed that the width of the tube extended almost the entire width of the trough between consecutive ridges and as such the fin efficiency begins to approach unity. In Figure 9 it can be seen that decreasing the ratio of tube width to spacing $(d / W)$ causes the thermal efficiency of the collector to decrease for a constant hydraulic diameter. Similarly it can be seen in Figure 10 that having a large ratio $d / W$ results in a significant improvement in the electrical efficiency. However it is clear that this relationship is asymptotic, this suggests that although there are benefits in increasing this ratio, as has been done for this design, there are other factors which are reducing the performance of the BIPVT.

Another way in which heat transfer can be improved is by increasing the thermal conductivity between the PV cells and the absorber plate. In Table 2, and the experiment, a value of $45 \mathrm{~W} / \mathrm{m}^{2} \mathrm{~K}\left(h_{P V A}\right)$ was used as a "quasi" heat transfer coefficient between the PV cells and the absorber plate, rather than the bond resistance normally used in the Hottel-Whillier-Bliss equations (the experimental derivation of this value was reported and discussed by de Vries (1998) and Zondag et.al. (2002)). Furthermore, de Vries noted that this experimental value was low in comparison to his theoretical value of $450 \mathrm{~W} / \mathrm{m}^{2} \mathrm{~K}$. Based on this it was assumed that it could be increased by the use of thermally conductive adhesives to join the cells to the absorber. In Figure 11 it can be seen that by increasing the value of this "quasi" heat transfer coefficient to $135 \mathrm{~W} / \mathrm{m}^{2} \mathrm{~K}$, that the maximum thermal efficiency is improved by approximately 5\%. Given that the high thermal conductivity adhesives are commonly used in 
attaching electrical components to heatsinks to improve cooling, it was evident that using these to attach the PV cells in the BIPVT would also improve the electrical efficiency. In Figure 12 it can be seen that by reducing the bond thermal resistance, there is a marked increase in the electrical efficiency. As such, it would be prudent to ensure that thermal conductivity between these bodies is maximised. However, it should also be recognised that these results are also asymptotic, suggesting other areas that are limiting the efficiency of the BIPVT.

In addition to improving the heat transfer between the absorber and the PV cells, it may be possible to improve the optical efficiency of the BIPVT system by reducing the reflectance of the PV cells. In Table 2, a value of 0.74 was specified for the transmittance/absorptance product for the PV cells. de Vries (1998) derived this value from a theoretical optical analysis of a photovoltaic laminate and found that it compared well with an experimentally determined value of 0.7 for a PVT collector producing electricity. However, Coventry (2004) found that for his concentrating PVT system that the transmittance/absorptance product was 0.82 . This difference can be explained by the differing lamination methods and materials and the method of practical implementation that were analysed by these authors. de Vries analysed a "typical” PV laminate using EVA encapsulation, whereas Coventry used Silicone encapsulation. Moreover, Santbergen and van Zolingen (2006) suggested a number of modifications that could be made to PV cells, such as replacing the back contact with a material with a greater absoptance of long-wave radiation, in order to increase the transmittance/absorptance product for PVT collectors.

From Figure 13 it is clear that by increasing the transmittance/absorptance product, that the thermal efficiency can be improved. The reason for this improved performance is related to the spectral absorption characteristics of PV cells, typically these respond well to short wavelengths, in the range from $400 \mathrm{~nm}$ up to approximately $1200 \mathrm{~nm}$. The solar spectrum however continues to approximately 2500nm and these long wavelengths tend to be reflected from PV cells, whereas they are absorbed by solar thermal collectors. The modifications suggested by Santbergen and van Zolingen (2006) were 
aimed at increasing the absorption of these longer wavelengths, while the use of a silicone encapsulant by Coventry (2004) meant that a greater portion of the longer wavelengths were absorbed by the silicone whose spectral properties were shown to absorb longer wavelengths. One of the drawbacks of increasing the absorption of longer wavelengths is that it tends to result in the PV cell temperature being increased. However, in Figure 14 it can be seen that, assuming these modifications do not change the efficiency or thermal properties of the cell, that the reduction in electrical efficiency is relatively minor.

As an alternative method for improving the thermal efficiency it is possible to vary the area that is covered by PV cells. In Table 2 a value of 0.925 was taken as the transmittance/absorptance product for the absorber to which the PV cells were mounted, this is typical of the transmittance-absorptance product for a commercial black painted roofing material (Weerakoon, 2008). As this is greater than the unmodified PV cells with a transmittance/absorptance product of 0.74 it is apparent that by decreasing the area covered by PV cells that the thermal efficiency increases. In Figure 15 it can be seen that increasing the area covered by PV cells does reduce the thermal efficiency. Obviously, however, reducing the area covered by PV cells also means that the overall electrical output is reduced.

Previously it was noted that the transmittance/absorptance product of 0.74 could be improved by altering the lamination method of the PV cells. Another simple method is to remove the glazing (cover) from the PVT panel. The presence of glazing means that not all the available radiation is transmitted to the PV cells as some is absorbed or reflected by the glazing. As such removing the glazing should improve the maximum efficiency. de Vries (1998) suggested that an unglazed PVT would have a transmittance/absorptance product of 0.78 .

However, it should also be noted that in an unglazed situation the thermal efficiency of the collector is strongly related to the heat loss. In essence, a glazed collector has a "pocket" of air trapped between the absorber plate and the glazing that suppresses the heat loss due to forced convection by the wind. 
As this layer of air is not present in an unglazed collector the convection and radiation heat loss dominates the performance of the collector, in particular the collector is far more sensitive to wind induced losses. In Figure 16, it can be seen that the maximum thermal efficiency is not as high as the previously illustrated cases and reduces significantly at increasing wind speeds. This reduction in efficiency is due to the decrease in the mean plate temperature caused by the heat loss to the environment; conversely however the electrical efficiency increases with increasing wind speed as shown in Figure 17.

Furthermore, it should be noted that the reduced thermal efficiency is not necessarily an entirely negative point. In fact if the system were to be coupled with a heat pump system, the lower inlet temperatures, typically below ambient, would mean that the efficiency of the unglazed BIPVT would be advantageous. This is due to the fact that the thermal, and electrical, efficiency of the BIPVT collector would increase beyond what is shown, at temperatures below ambient.

The results presented so far have essentially treated the BIPVT collector as a typical solar collector mounted at a fixed inclination. As such, if we were to use the standard treatment for heat loss from the rear surface of a collector we can see in Figure 18 that the efficiency changes with respect to the thickness of the insulation on the rear surface of the collector.

However, the BIPVT is in fact also a roofing or façade element and in a typical "cold roof" system the buildings insulation is placed at the ceiling level rather than on the rear surface of the roof (or in this case BIPVT). Thus, the back surface heat transfer occurs via natural convection in the attic space. In Figure 19 it can be seen that by reducing the inclination of the BIPVT the thermal efficiency also reduces. This is particularly pronounced at low roof inclinations with high temperature gradients. This suggests that if natural convection in an attic space is used as an alternative to insulating the rear surface of a BIPVT collector, that the pitch (angle) of the roof has a significant influence on the BIPVT thermal efficiency. However, this effect becomes less pronounced as the pitch is increased. 
These findings indicate that the rear air space in the attic can provide a level of insulation equivalent to a highly insulating material; essentially this is what the glazing on the front surface does. As such, there is obvious scope for reducing the cost of construction of a BIPVT by effective integration with the roof space. At the most basic level it is possible to rely on natural convection in attic spaces or wall cavities to provide a satisfactory degree of insulation and reduce the need for unnecessary rear surface insulation.

\section{CONCLUSION}

From the results presented it has been shown that there are a number of parameters that can be varied in the design of a BIPVT collector to maximise performance. The fact that the collector base material made little difference to the thermal efficiency of the BIPVT suggests that lower cost materials, such as steel, could be utilised for these systems. The validity of this hypothesis was most clearly demonstrated in the successful testing of an experimental BIPVT collector manufactured from precoated steel. The disadvantage of using steel is that the electrical efficiency would be decreased marginally.

To a certain extent this disadvantage can be overcome by maximising the ratio of the cooling tube width to spacing. This parameter was shown to improve both the thermal and electrical efficiency. Similarly, it was highlighted that good thermal contact between the PV cells and the absorber needs to be made; this could be achieved using thermally conductive adhesives and will improve both the electrical and thermal efficiencies of the system.

Additionally, any modifications that can be made to improve the absorption of long-wave radiation should be considered. As was shown, increasing the transmittance/absorptance product results in the greatest increase in thermal efficiency of all the parameters assessed, without greatly reducing the 
electrical efficiency. Furthermore the use of unglazed BIPVT systems in conjunction with heat pumps could present interesting possibilities.

Finally, there appears to be significant potential to utilise the low natural convection heat transfer in the attic at the rear of the BIPVT to act as an insulating layer rather than using additional insulation material. The use of this air layer would allow the material cost of such a system to be significantly reduced.

\section{REFERENCES}

AS/NZS 2535.1, 1999, “Test methods for solar collectors Part 1: Thermal performance of glazed liquid heating collectors including pressure drop”, Standards Australia, Homebush

Bazilian, M.D., Leenders, F., van Der Ree, B.G.C. and Prassad, D., 2001, "Photovoltaic cogeneration in the built environment”, Solar Energy, v 71, no. 1, pp. 57-69

Bazilian, M.D., Kamalanathan, H., and Prasad, D., 2002, "Thermographic analysis of a building integrated photovoltaic system”, Renewable Energy, v 26, n 3, pp. 449-461

Bergene, T. and Lovvik, O.M., 1995, "Model calculations on a flat-plate solar heat collector with integrated solar cells”, Solar Energy, v 55, no. 6, pp. 453-462

Chow, T.T., He, W. and Ji, J., 2006, "Hybrid photovoltaic-thermosyphon water heating system for residential application”, Solar Energy, Vol.80, pp. 298-306

Coventry, J.S., 2004, “A solar concentrating photovoltaic/thermal collector”, PhD Thesis, Australian National University 
De Vries, D.W., 1998, “Design of a photovoltaic/thermal combi-panel”, PhD thesis, Eindhoven University

Duffie, J.A. and Beckman, W.A., 2006, “Solar engineering of thermal processes”, Wiley, New York

Eicker, U., 2003, “Solar technologies for buildings”, John Wiley and Sons, Chichester

Florschuetz, L.W., 1979, "Extension of the Hottel-Whillier model to the analysis of combined photovoltaic/thermal flat plate collectors”, Solar Energy, v 22, no. 4, pp. 361-366

Fuentes, M.K., 1987, “A simplified thermal model for flat-plate photovoltaic arrays”, Sandia National Laboratories Report, SAND85-0330-UC-63, Albuquerque

Green, M., 1998, “Solar Cells: Operating Principles, Technology and System Applications”, The University of New South Wales, Kensington, Australia

He, W., Chow, T.T., Lu, J., Pei, G., Chan, L., 2006, “Hybrid photovoltaic and thermal solar-collector designed for natural circulation of water”, Applied Energy, Vol.83, pp.199-210

Krauter, S.C.W., 2006, “Solar electric power generation: Photovoltaic energy systems”, SpringerVerlag, Heidelberg

Medved, S., Arkar, C. and Cerne, B., 2003, “A large-panel unglazed roof-integrated liquid solar collector-energy and economic evaluation”, Solar Energy, v 75, n 6, 2003, pp 455-467

Prasad, D and Snow, M., 2005, “Designing with solar power”, Images Publishing Group, Melbourne 
Ridouane, E.H. and Campo, A., 2005, “Experimental-based correlations for the characterization of free convection of air inside isosceles triangular cavities with variable apex angles”, Experimental Heat Transfer, v 18, no. 2, pp 81-86

Santbergen, R. and van Zolingen, R.J.C., 2006, "Modeling the thermal absorption factor of photovoltaic/thermal combi-panels”, Energy Conversion and Management, v 47, pp. 3572-3581

Tripanagnostopoulos, Y., Nousia, T., Souliotis, M. and Yianoulis, P., 2002, "Hybrid photovoltaic/thermal solar systems”, Solar Energy, Vol.72, No.3, pp.217-234

van Helden, W.G.J., van Zolingen, R.J.C. and Zondag, H.A., 2004, "PV thermal systems: PV panels supplying renewable electricity and heat”, Progress in Photovoltaics: Research and Applications, v 12, pp. $415-426$

Vokas, G., Christandonis, N., and Skittides, F., 2006, "Hybrid photovoltaic-thermal systems for domestic heating and cooling-A theoretical approach”, Solar Energy, v 80, n 5, pp. 607-615

Watmuff, J.H., Charters, W.W.S., and Proctor, D., 1977, "Solar and wind induced external coefficients for solar collectors”, Comples No. 2, 56

Weerakoon, A.N., 2008, “Use of corrugated panels as transpired solar collectors”, Unpublished PhD Thesis, University of Auckland

Zondag, H.A., de Vries, D.W., van Helden, W.G.J., van Zolingen, R.J.C., and van Steenhoven, A.A., 2002, "The thermal and electrical yield of a PV-thermal collector", Solar Energy, v72, n2, pp.113-128 
Table 1: Prototype experimental BIPVT physical characteristics

\begin{tabular}{|c|c|c|c|}
\hline Parameter & Symbol & Value & Unit \\
\hline Number of covers & $N$ & 1 or 0 & \\
\hline Emittance of plate & $\varepsilon_{p}$ & 0.95 & \\
\hline Emittance of cover & $\varepsilon_{c}$ & 0.88 & \\
\hline Number of tubes & $n$ & 2 & \\
\hline System flow rate & $m$ & 2 & $\mathrm{l} / \mathrm{min}$ \\
\hline Collector Length & $L$ & 1.96 & $\mathrm{~m}$ \\
\hline Collector Breadth & $b$ & 0.5 & $\mathrm{~m}$ \\
\hline Collector Area & $A_{\text {collector }}$ & 0.98 & $\mathrm{~m}^{2}$ \\
\hline $\begin{array}{l}\text { PV Trans/Abs } \\
\text { (de Vries, 1998) }\end{array}$ & $\tau \alpha_{P V}$ & 0.74 or 0.78 & \\
\hline $\begin{array}{l}\text { Thermal Trans/Abs } \\
\text { (Weerakoon, 2008) }\end{array}$ & $\tau \alpha_{T}$ & 0.925 & \\
\hline Absorber thickness & $t$ & 0.5 & $\mathrm{~mm}$ \\
\hline PV thickness & $L_{P V}$ & 0.4 & $\mathrm{~mm}$ \\
\hline $\begin{array}{l}\text { PV conductivity } \\
\text { (Krauter, 2006) }\end{array}$ & $k_{p v}$ & 130 & $\mathrm{~W} / \mathrm{mK}$ \\
\hline Tube Hydraulic Diameter & $d_{h}$ & 8 & $\mathrm{~mm}$ \\
\hline Tube Spacing & $W$ & 0.23 & $\mathrm{~m}$ \\
\hline $\begin{array}{l}\text { Ratio of Tube width to } \\
\text { spacing }\end{array}$ & $d / W$ & 0.087 & \\
\hline $\begin{array}{l}\text { Heat transfer coefficient } \\
\text { from cell to absorber } \\
\text { (de Vries, 1998) }\end{array}$ & $h_{P V A}$ & 45 & $\mathrm{~W} / \mathrm{m}^{2} \mathrm{~K}$ \\
\hline Insulation Conductivity & $k$ & 0.045 & $\mathrm{~W} / \mathrm{mK}$ \\
\hline Back Insulation Thickness & $L_{b}$ & 0.1 & $\mathrm{~m}$ \\
\hline Edge Insulation Thickness & $L_{\text {edge }}$ & 0.025 & $\mathrm{~m}$ \\
\hline Absorber Conductivity & $k_{a b s}$ & 50 & $\mathrm{~W} / \mathrm{mK}$ \\
\hline $\begin{array}{l}\text { Heat Removal Efficiency } \\
\text { Factor }\end{array}$ & $F_{R}$ & $\sim 0.6$ & \\
\hline $\begin{array}{c}\text { Collector Heat Loss } \\
\text { Coefficient }\end{array}$ & $U_{\text {loss }}$ & $\begin{aligned} & \sim 7 \text { (glazed) } \\
\sim & 25 \text { (unglazed) }\end{aligned}$ & $\mathrm{W} / \mathrm{m}^{2} \mathrm{~K}$ \\
\hline Packing Factor & $S$ & 0.4 & \\
\hline Mounting Angle & $\beta$ & 37 & degrees \\
\hline
\end{tabular}


Table 2: BIPVT physical characteristics

\begin{tabular}{|c|c|c|c|}
\hline Parameter & Symbol & Value & Unit \\
\hline Number of covers & $N$ & 1 or 0 & \\
\hline Ambient Temperature & $T_{a}$ & 293 & $\mathrm{~K}$ \\
\hline Emittance of plate & $\varepsilon_{p}$ & 0.95 & \\
\hline Emittance of cover & $\varepsilon_{c}$ & 0.88 & \\
\hline Number of tubes & $n$ & 66 & \\
\hline System flow rate & $m$ & 2 & $1 / \mathrm{s}$ \\
\hline Collector Area & $A_{\text {collector }}$ & 100 & $\mathrm{~m}^{2}$ \\
\hline Wind Speed & $v$ & 2 & $\mathrm{~m} / \mathrm{s}$ \\
\hline $\begin{array}{l}\text { PV Trans/Abs } \\
\text { (de Vries, 1998) }\end{array}$ & $\tau \alpha_{P V}$ & 0.74 or 0.78 & \\
\hline $\begin{array}{l}\text { Thermal Trans/Abs } \\
\text { (Weerakoon, 2008) }\end{array}$ & $\tau \alpha_{T}$ & 0.925 & \\
\hline Absorber thickness & $t$ & 0.5 & $\mathrm{~mm}$ \\
\hline PV thickness & $L_{P V}$ & 0.4 & $\mathrm{~mm}$ \\
\hline $\begin{array}{l}\text { PV conductivity } \\
\text { (Krauter, 2006) }\end{array}$ & $k_{p v}$ & 130 & $\mathrm{~W} / \mathrm{mK}$ \\
\hline Tube Hydraulic Diameter & $d_{h}$ & 9.7 & $\mathrm{~mm}$ \\
\hline Tube Spacing & $W$ & 0.1 & $\mathrm{~m}$ \\
\hline $\begin{array}{l}\text { Ratio of Tube width to } \\
\text { spacing }\end{array}$ & $d / W$ & 1.5 & \\
\hline $\begin{array}{l}\text { Heat transfer coefficient } \\
\text { from cell to absorber } \\
\text { (de Vries, 1998) }\end{array}$ & $h_{P V A}$ & 45 & $\mathrm{~W} / \mathrm{m}^{2} \mathrm{~K}$ \\
\hline Insulation Conductivity & $k$ & 0.045 & $\mathrm{~W} / \mathrm{mK}$ \\
\hline Edge Insulation Thickness & $L_{\text {edge }}$ & 0.025 & $\mathrm{~m}$ \\
\hline Absorber Conductivity & $k_{a b s}$ & 50 & $\mathrm{~W} / \mathrm{mK}$ \\
\hline $\begin{array}{l}\text { Heat Removal Efficiency } \\
\text { Factor (typical) }\end{array}$ & $F_{R}$ & $\sim 0.85$ & \\
\hline $\begin{array}{l}\text { Collector Heat Loss } \\
\text { Coefficient (typical) }\end{array}$ & $U_{\text {loss }}$ & $\begin{aligned} & \sim 6 \text { (glazed) } \\
\sim & 22 \text { (unglazed) }\end{aligned}$ & $\mathrm{W} / \mathrm{m}^{2} \mathrm{~K}$ \\
\hline Mounting Angle & $\beta$ & 37 & degrees \\
\hline
\end{tabular}




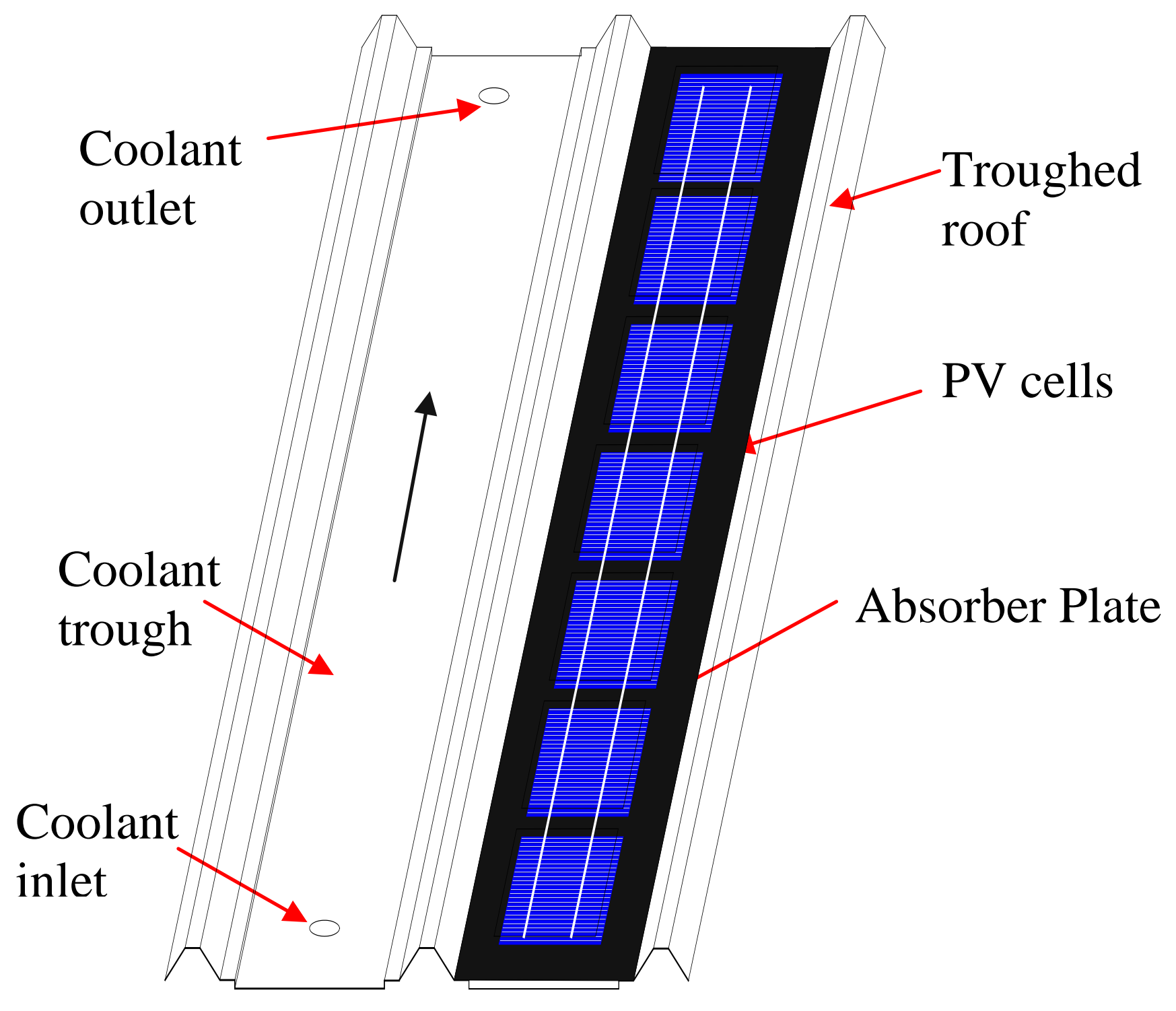

Figure 1: BIPVT Collector 


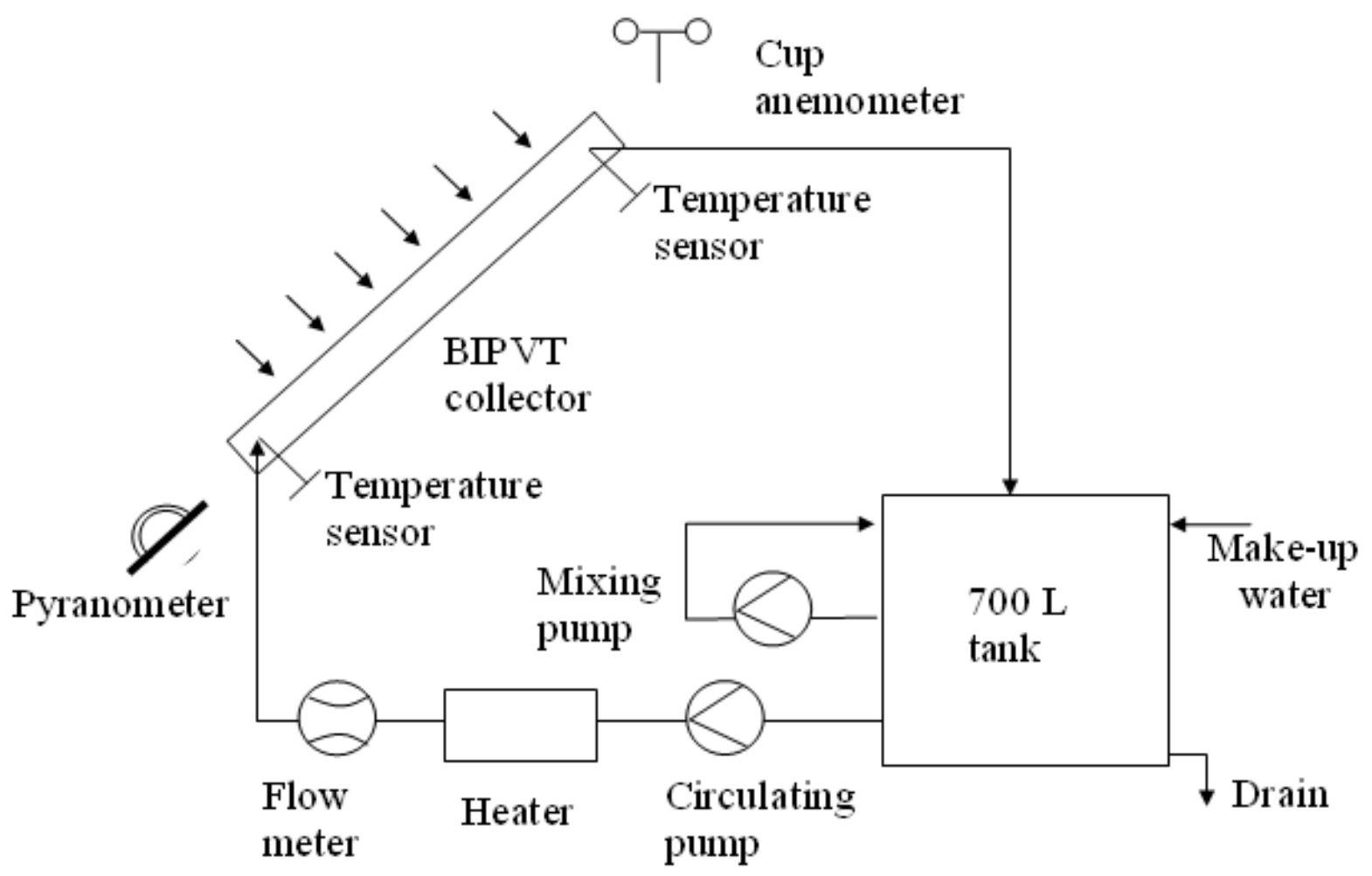

Figure 2: BIPVT test rig 


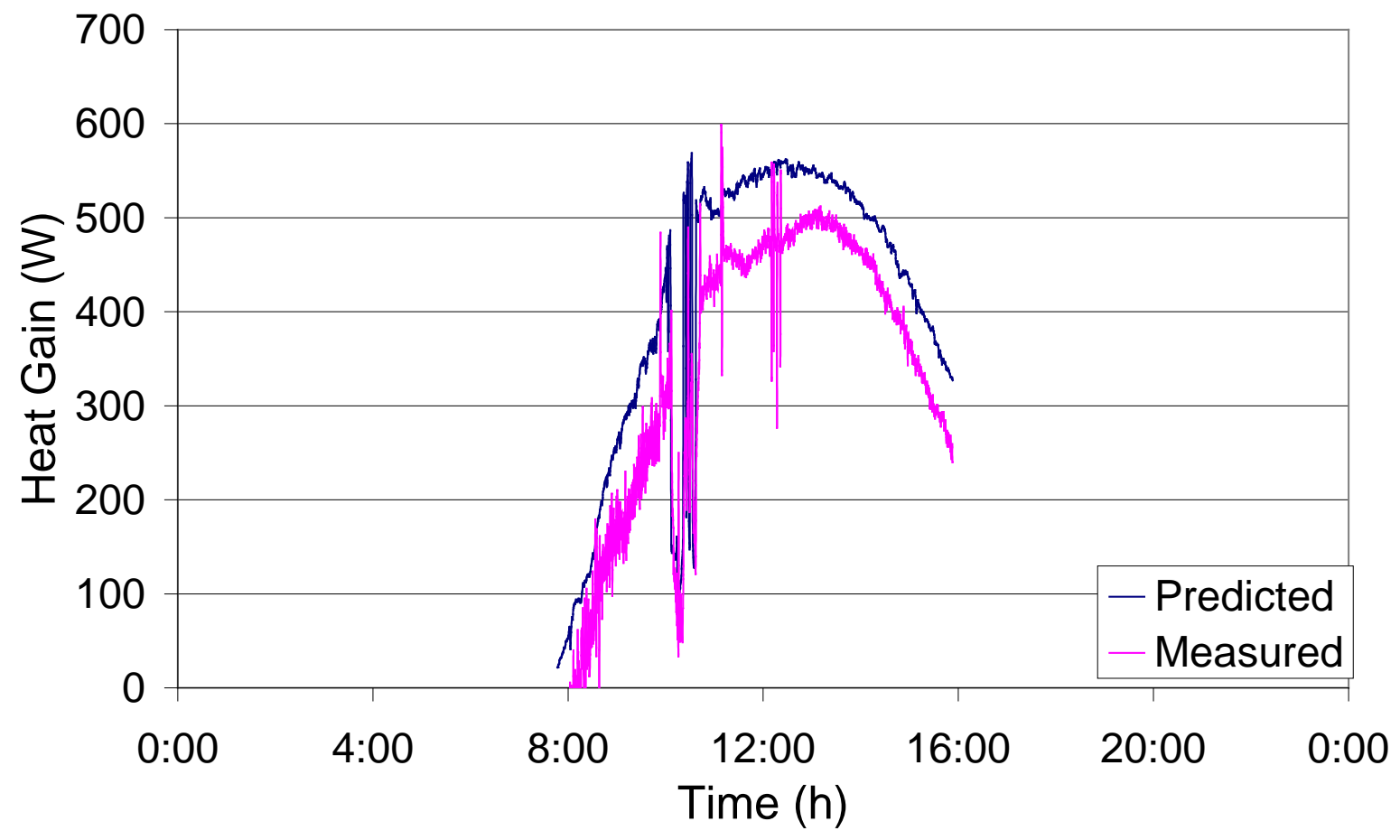

Figure 3: Predicted and measured heat gain by a glazed BIPVT collector 


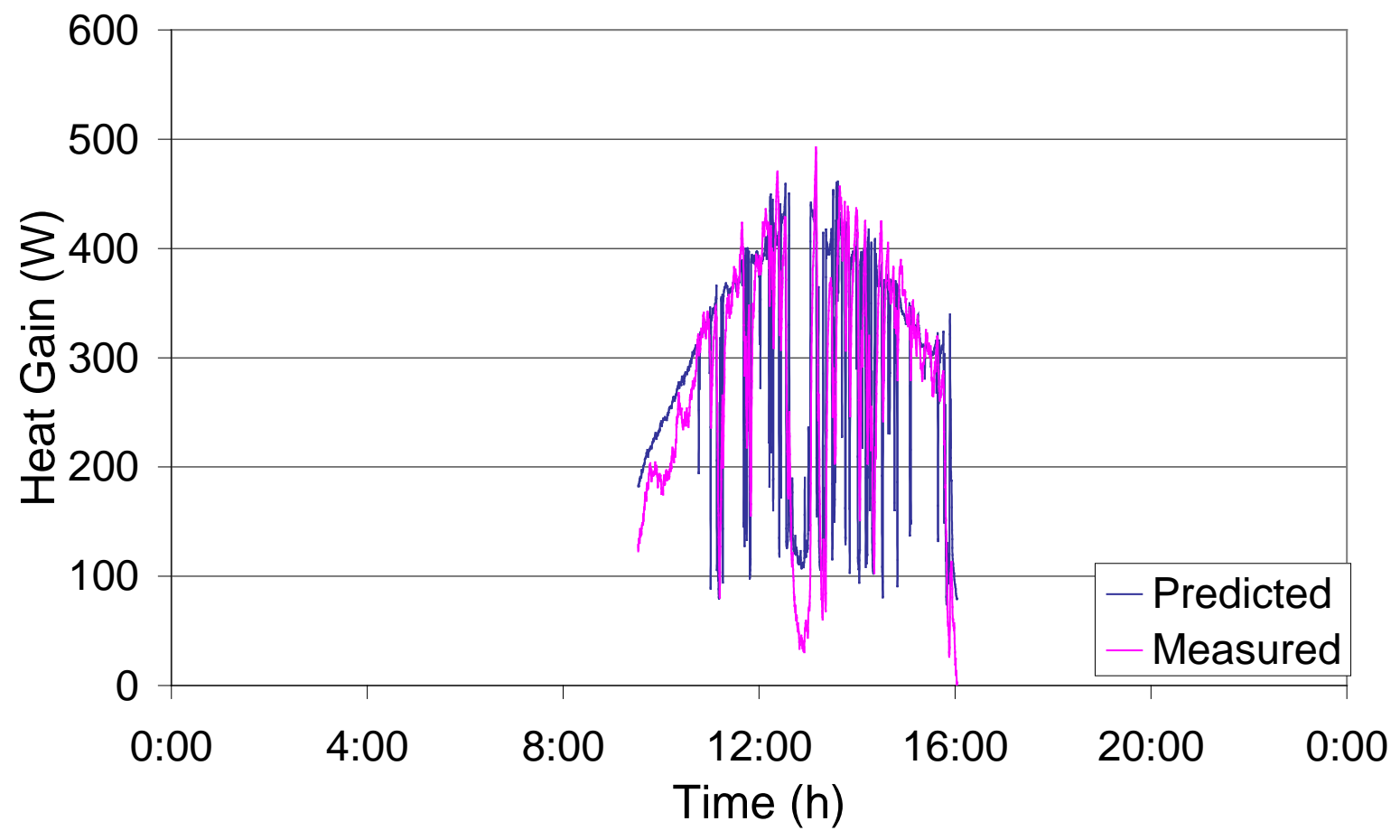

Figure 4: Predicted and measured heat gain by an unglazed BIPVT collector 


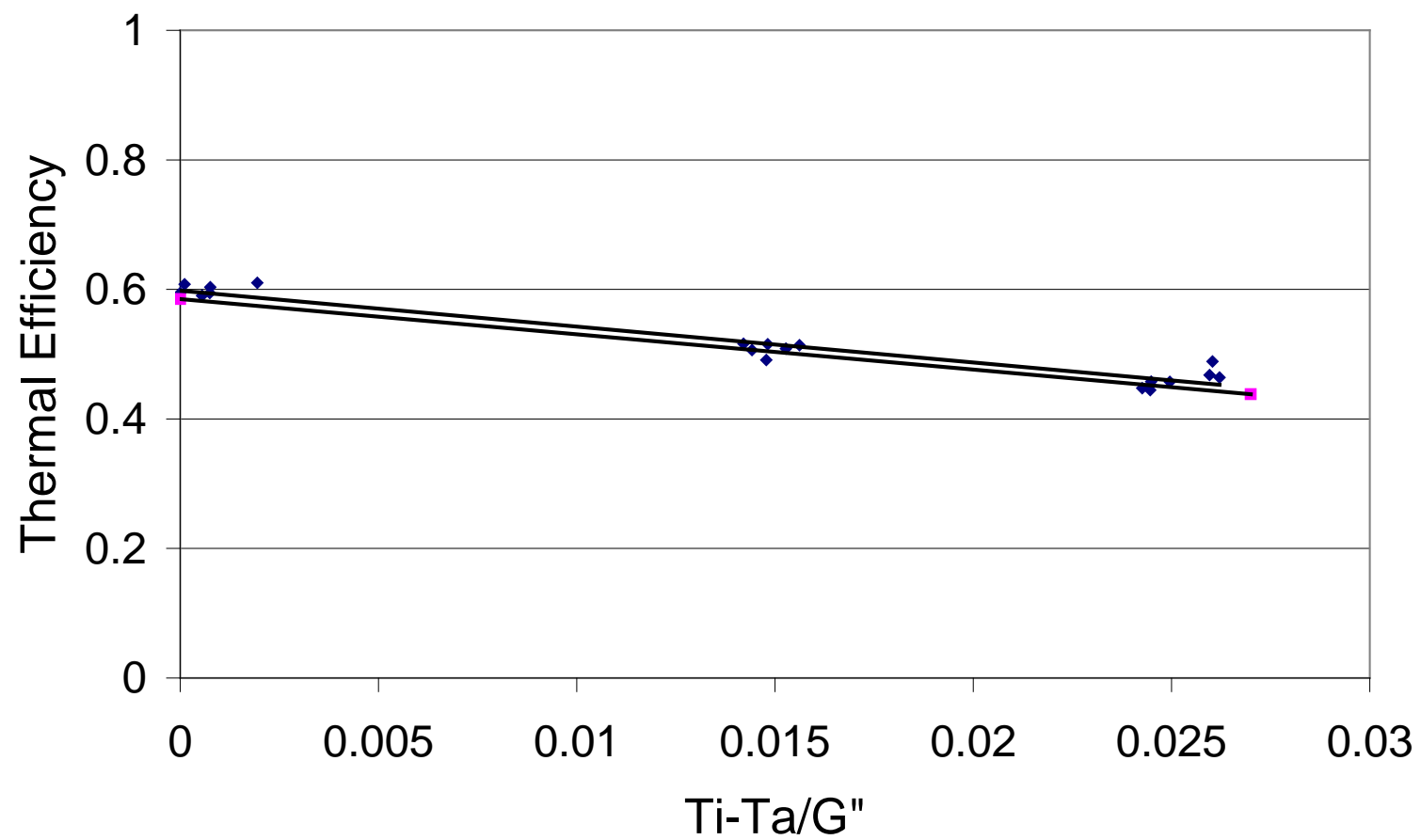

Figure 5: Experimental and theoretical thermal efficiency of a glazed BIPVT collector 


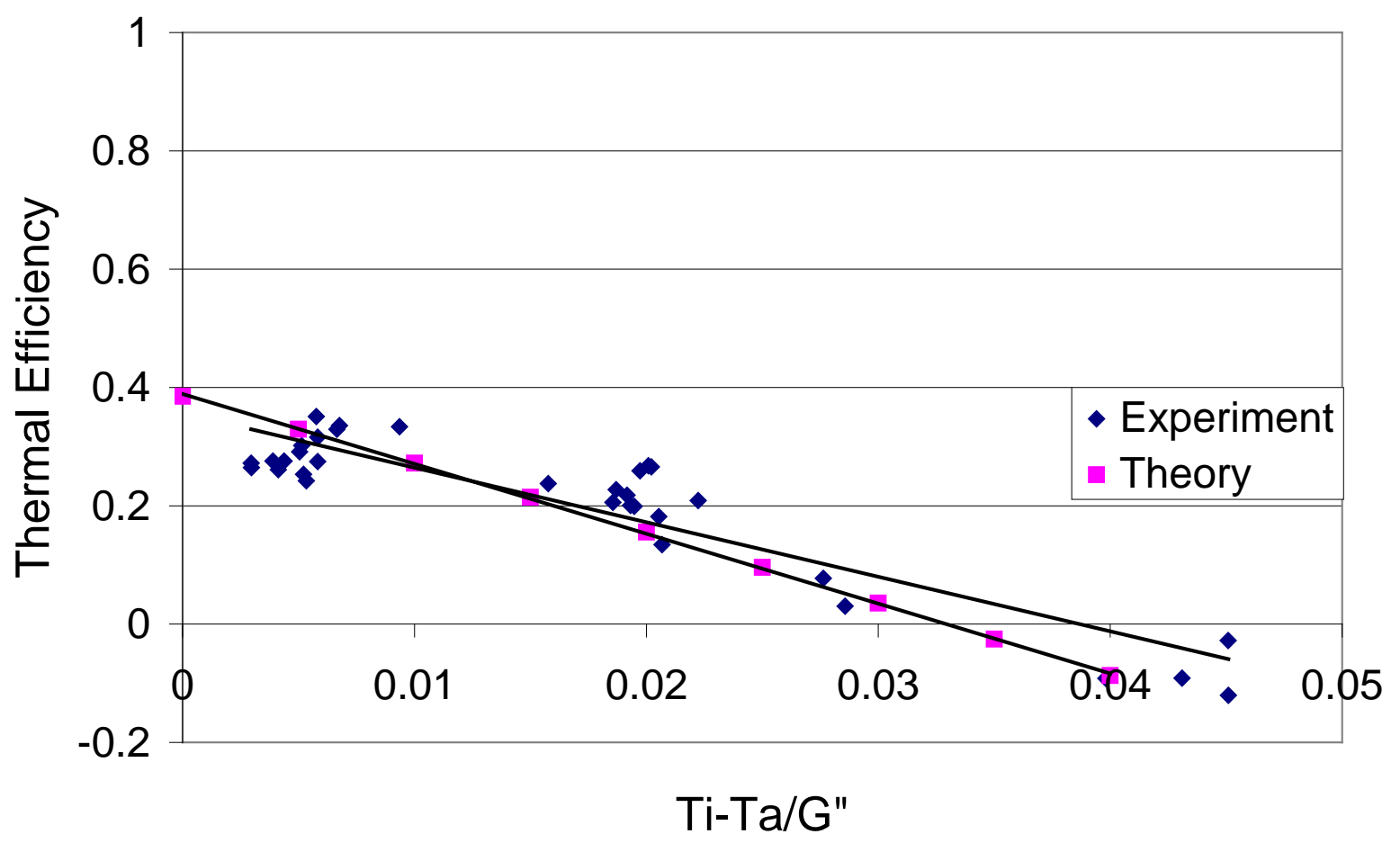

Figure 6: Experimental and theoretical thermal efficiency of an unglazed BIPVT collector 


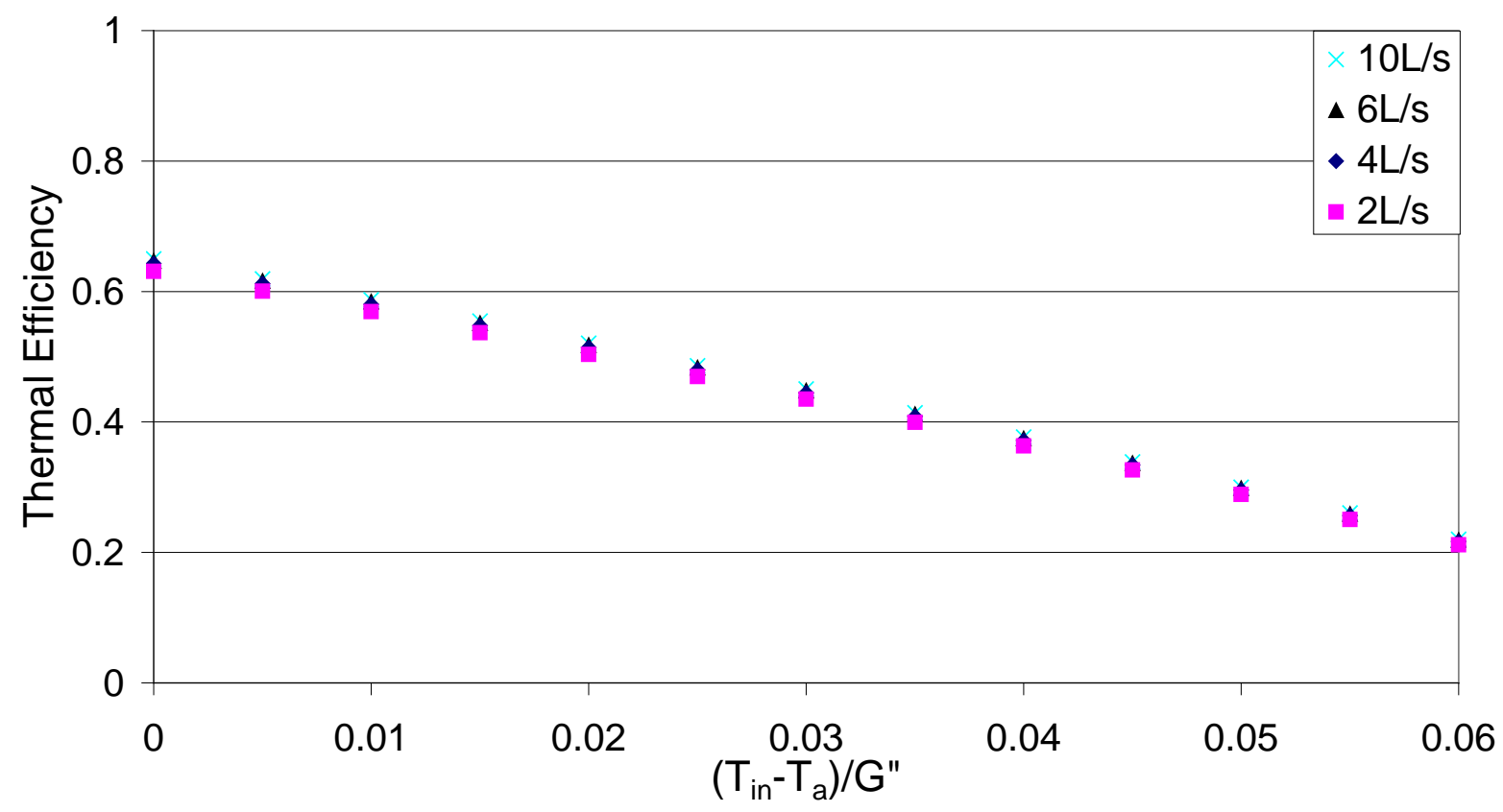

Figure 7: BIPVT thermal efficiency at varying flow rates 


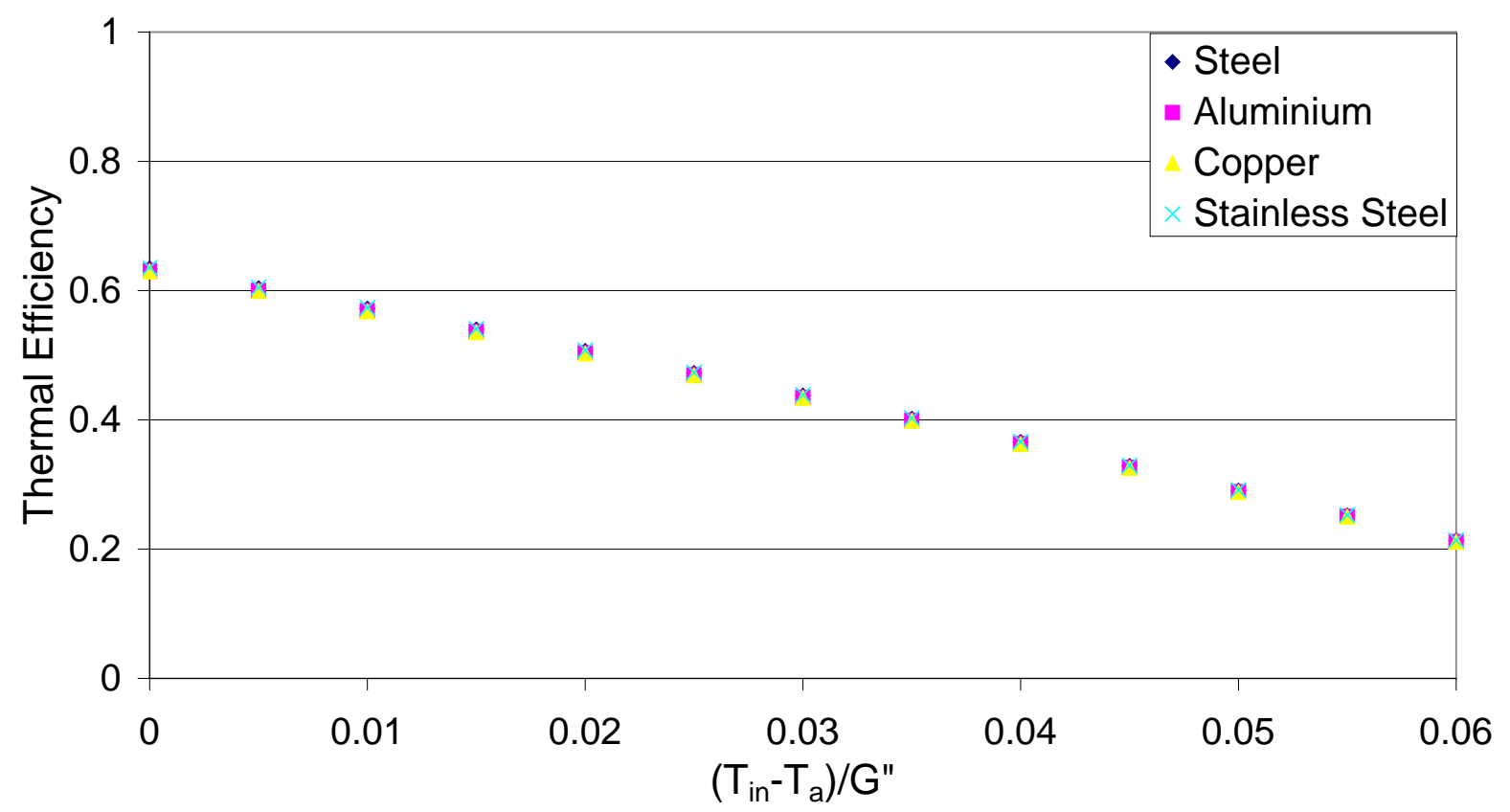

Figure 8: BIPVT thermal efficiency for varying collector materials 


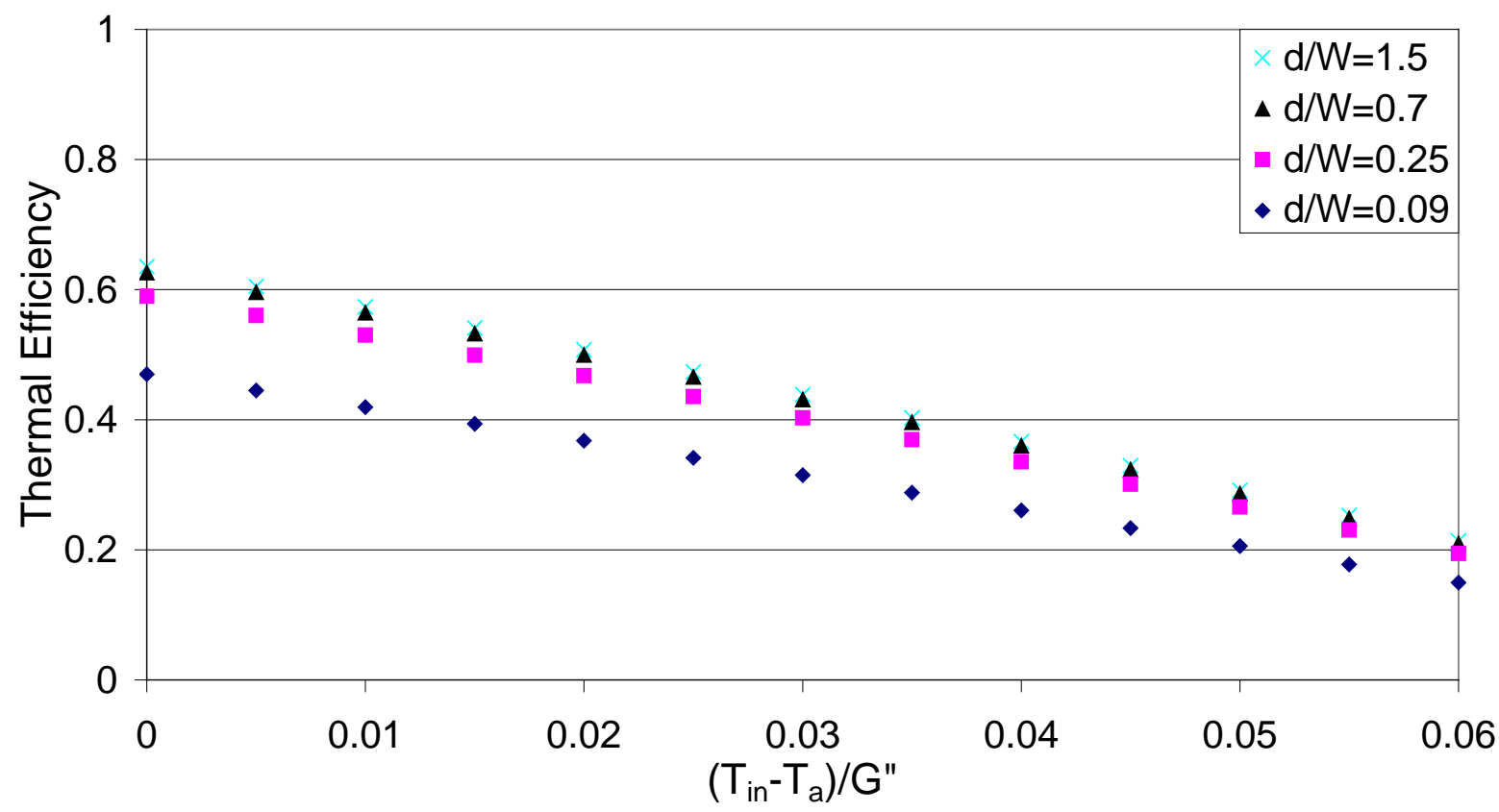

Figure 9: BIPVT thermal efficiency for varying tube width 


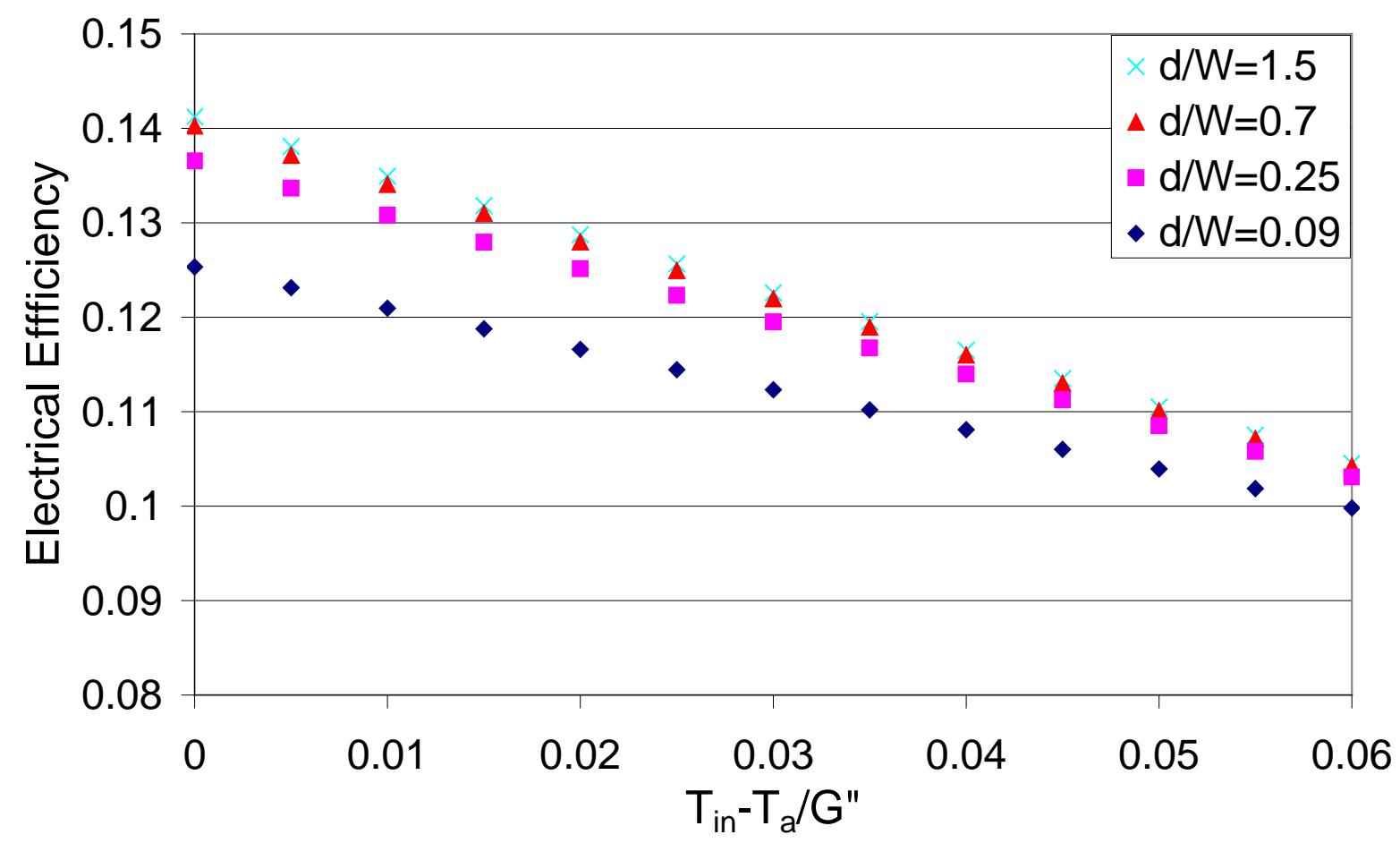

Figure 10: Electrical efficiency for varying tube width 


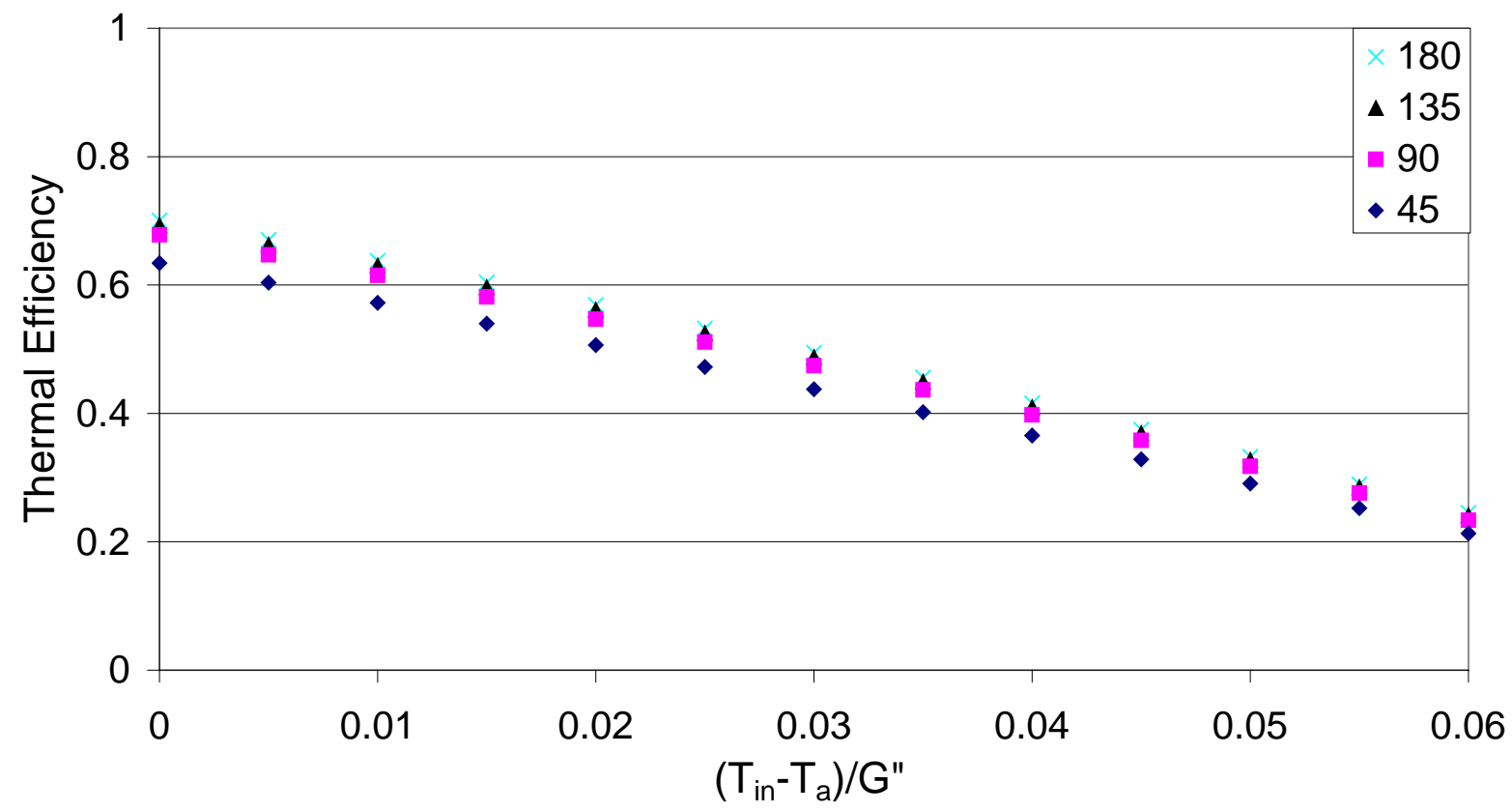

Figure 11: BIPVT thermal efficiency for varying PV to absorber conductivities 


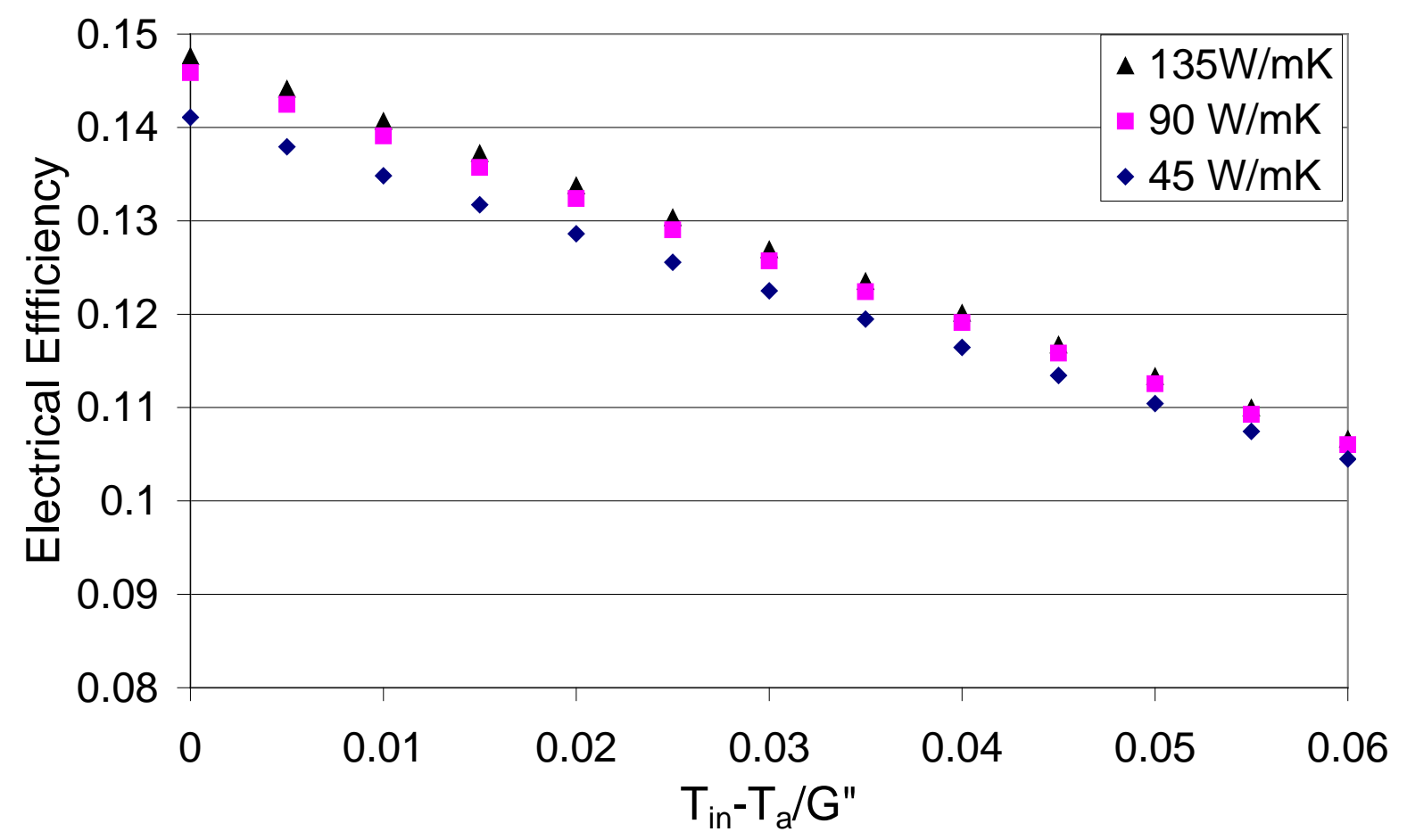

Figure 12: BIPVT electrical efficiency for varying PV to absorber conductivities 


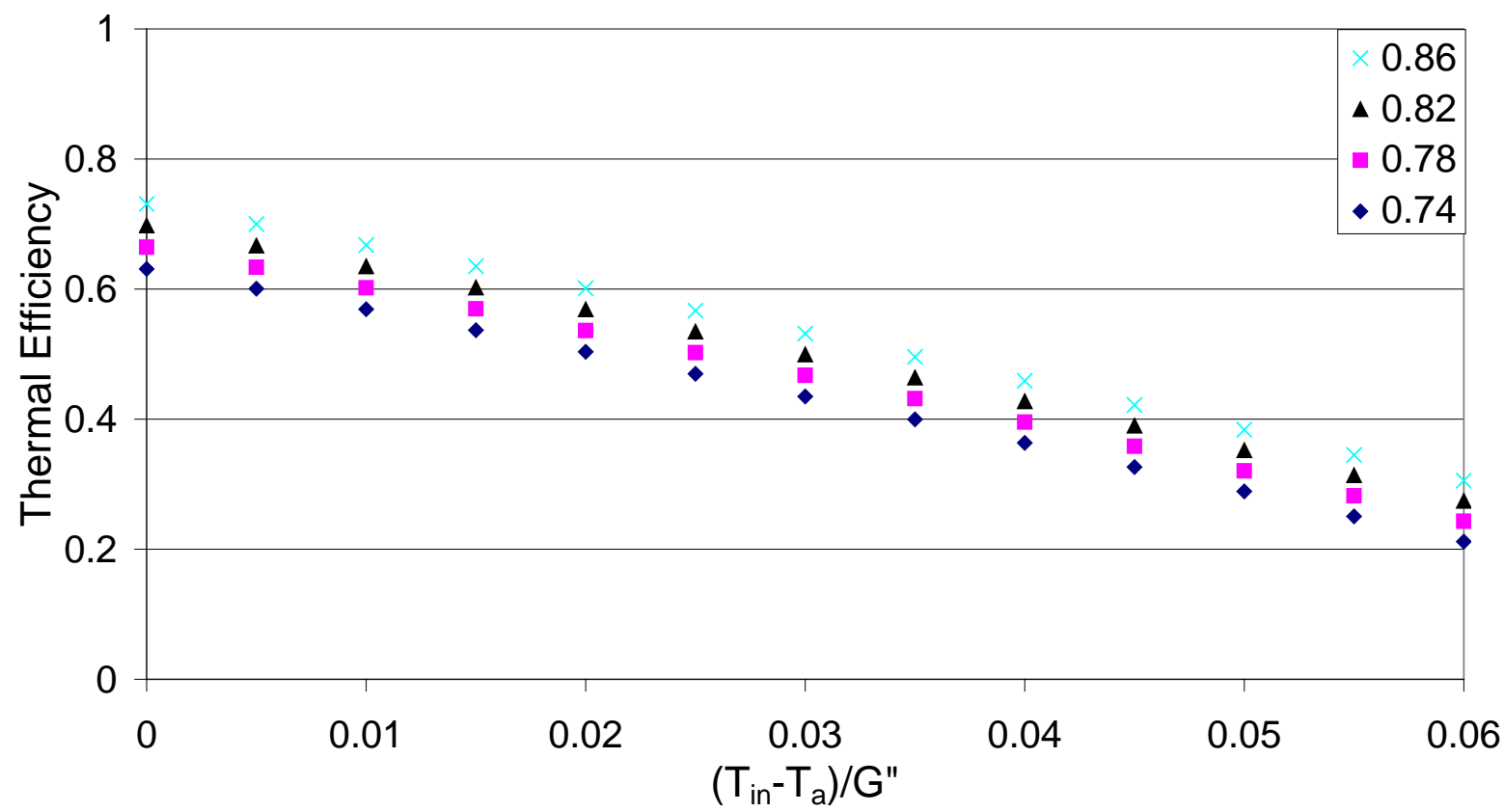

Figure 13: BIPVT thermal efficiency for varying transmittance/absorptance products 


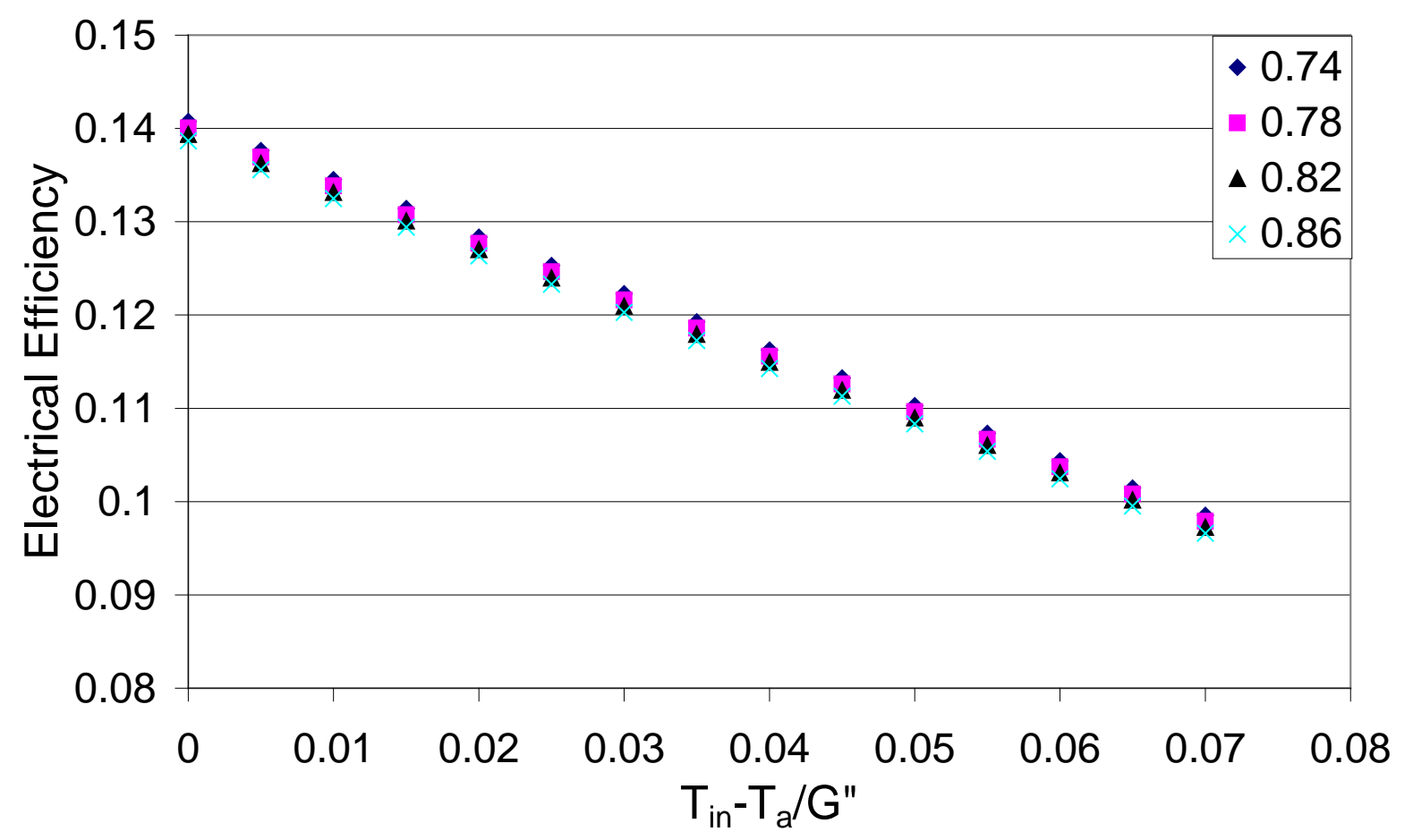

Figure 14: BIPVT electrical efficiency for varying transmittance/absorptance products 


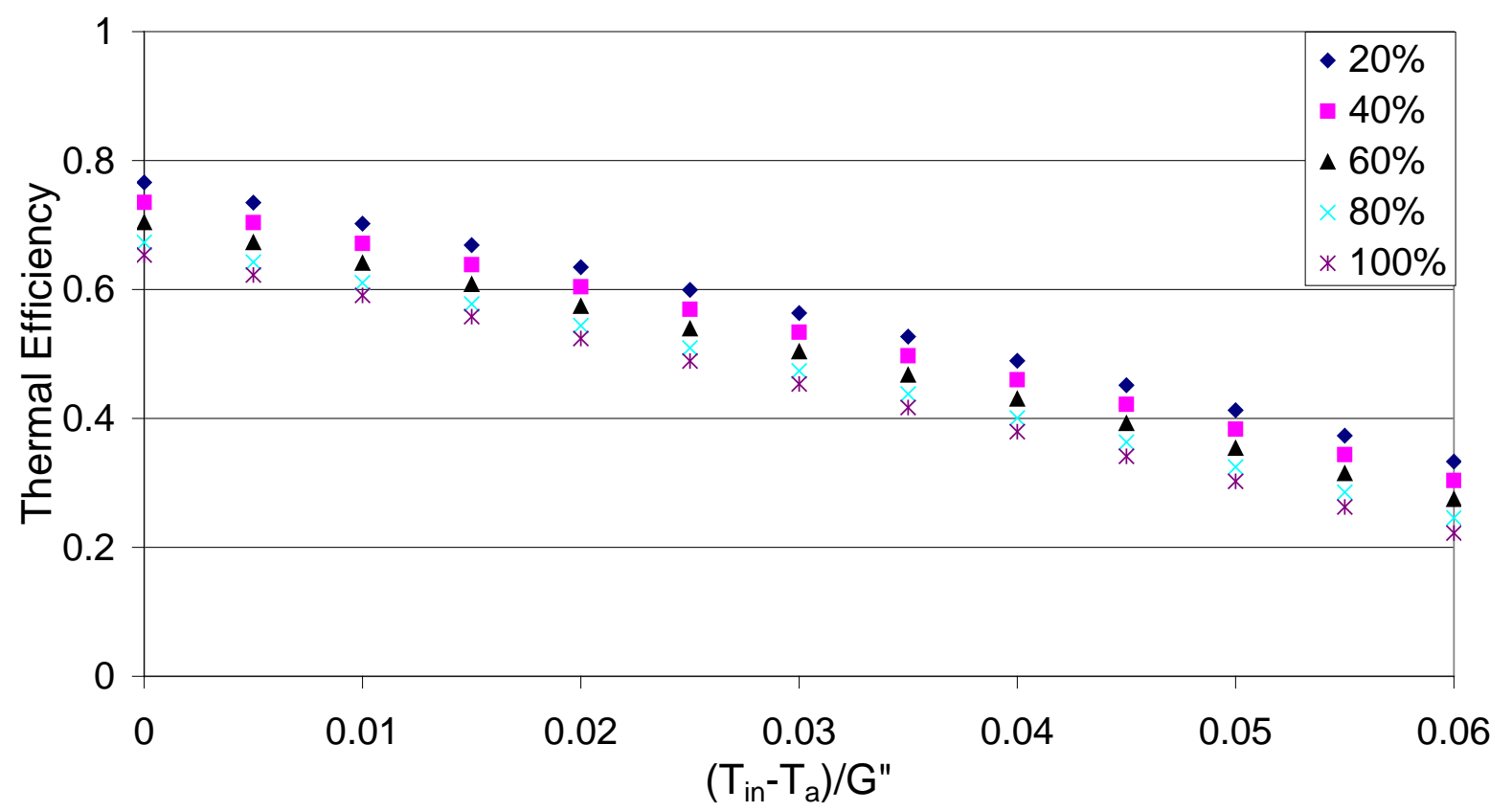

Figure 15: BIPVT thermal efficiency for varying PV area coverage 


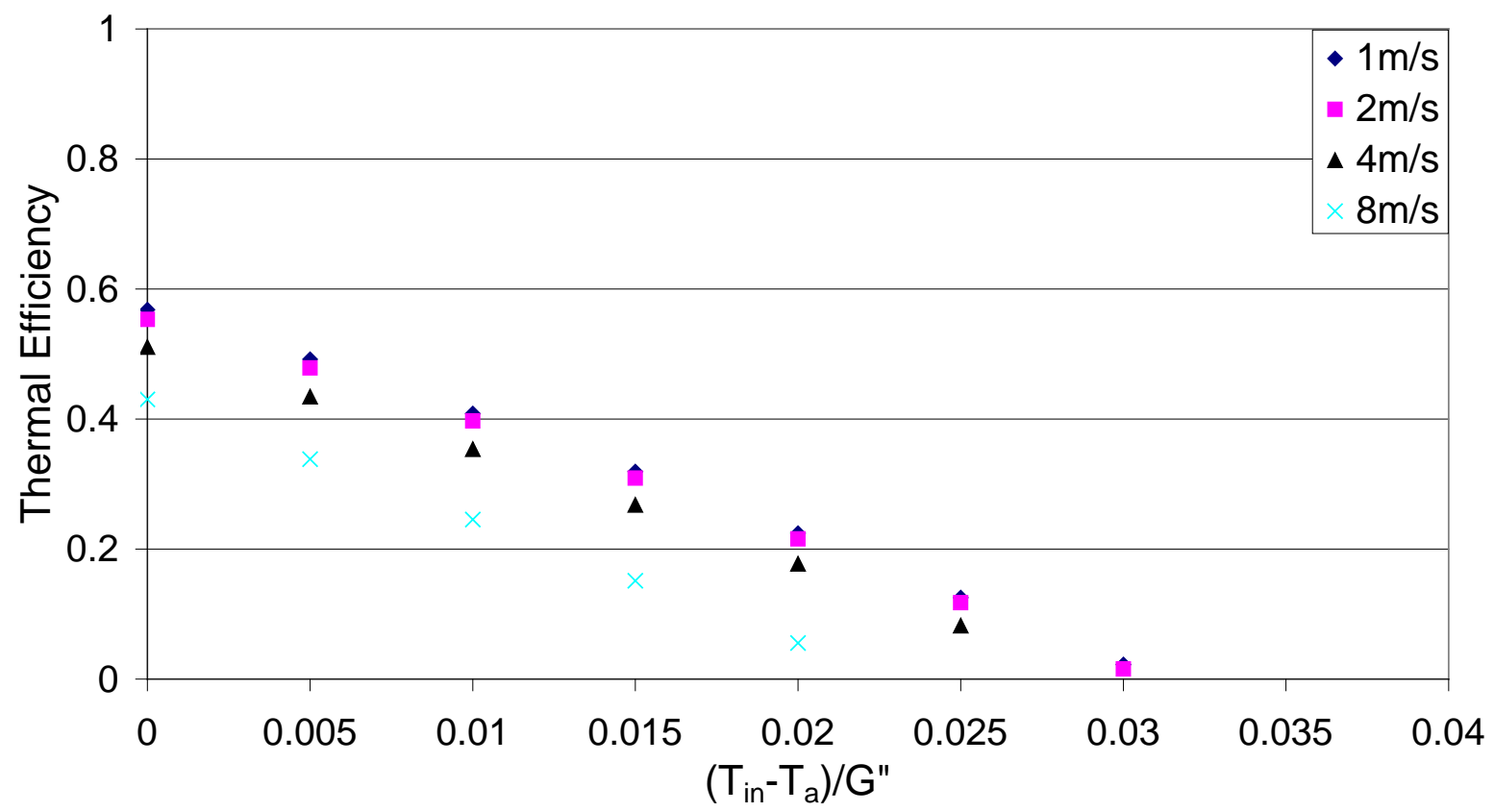

Figure 16: Unglazed BIPVT thermal efficiency for varying wind speeds 


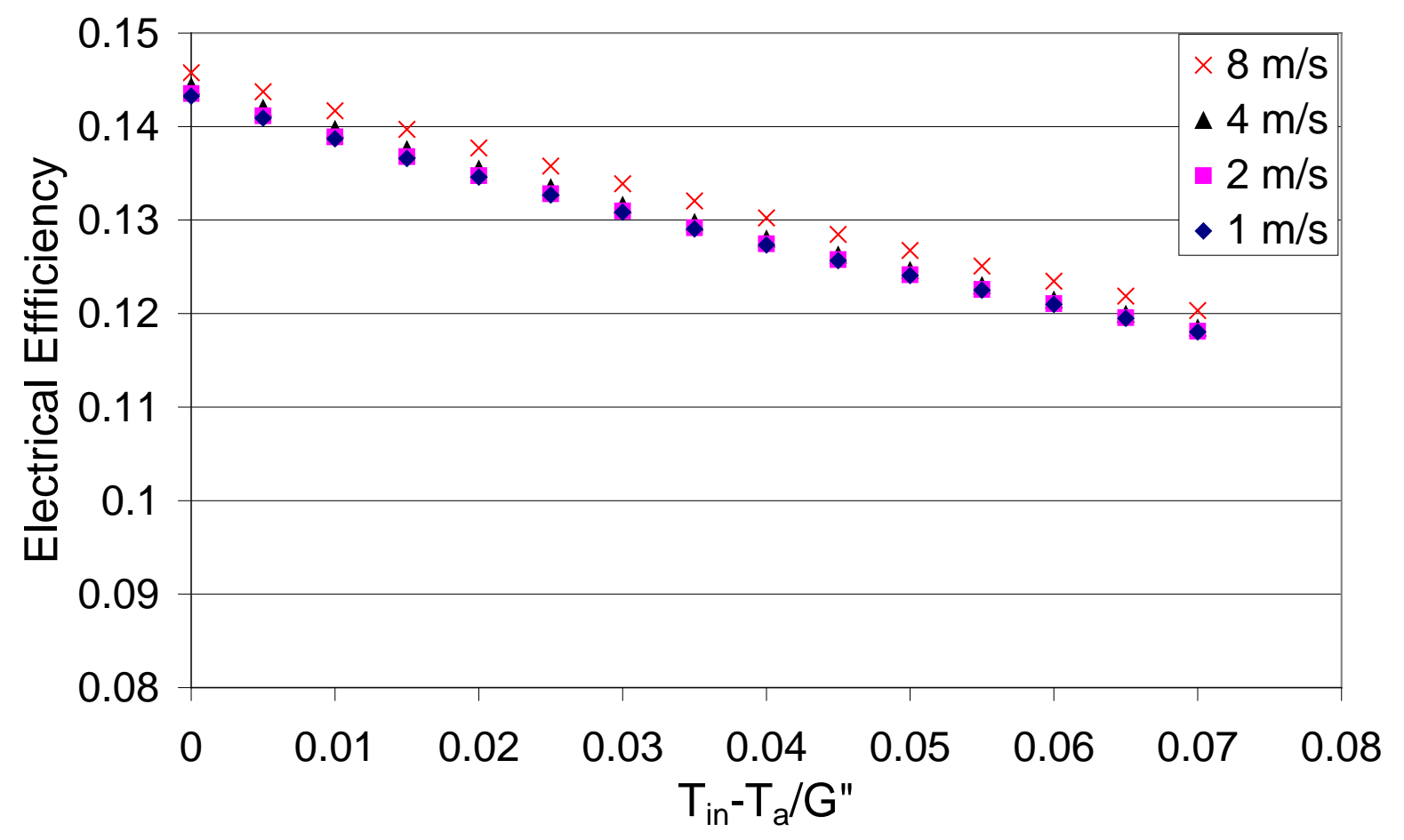

Figure 17: Unglazed BIPVT electrical efficiency for varying wind speeds 


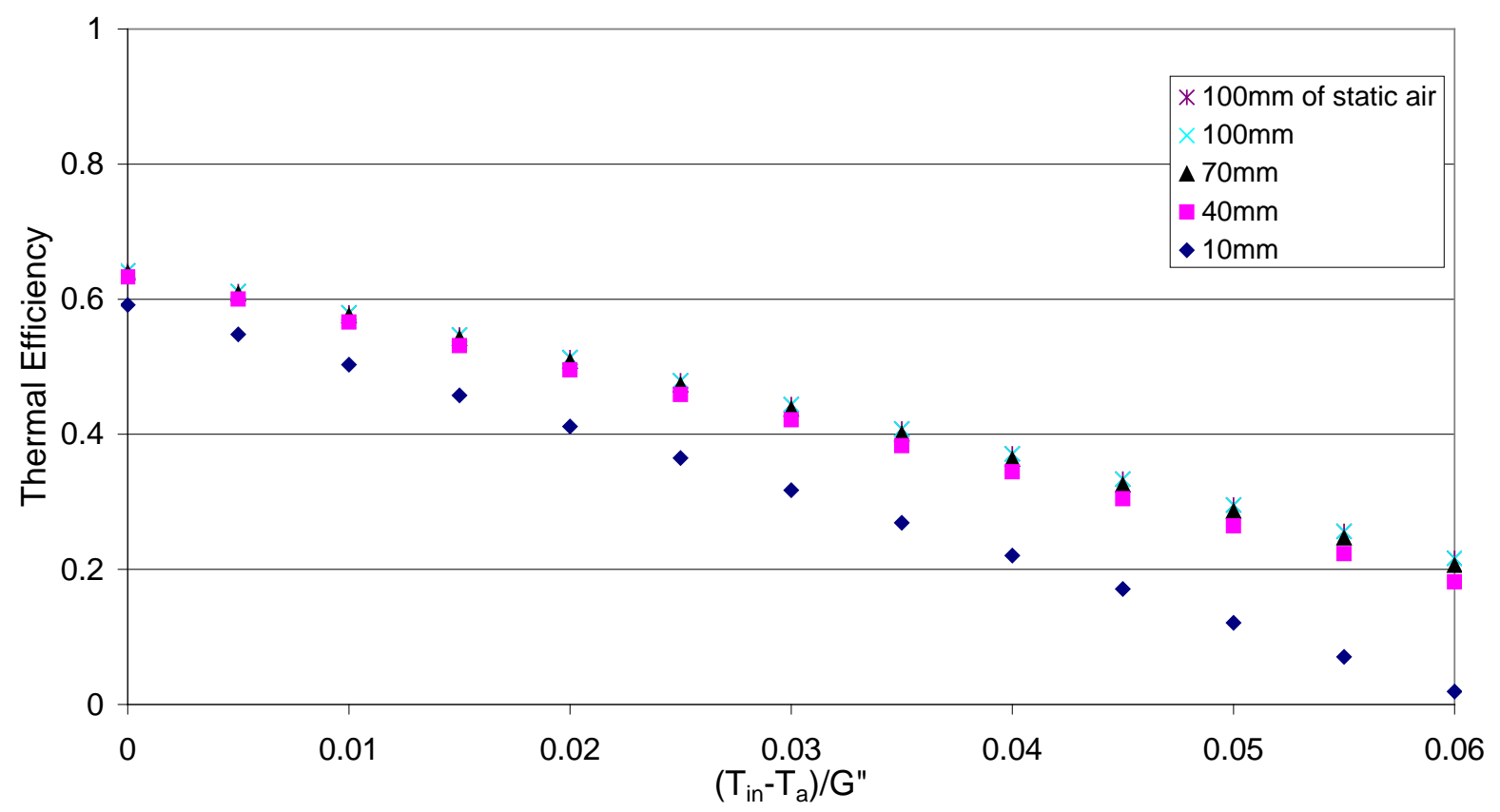

Figure 18: BIPVT thermal efficiency for varying insulation thickness assuming a stand-alone collector model 


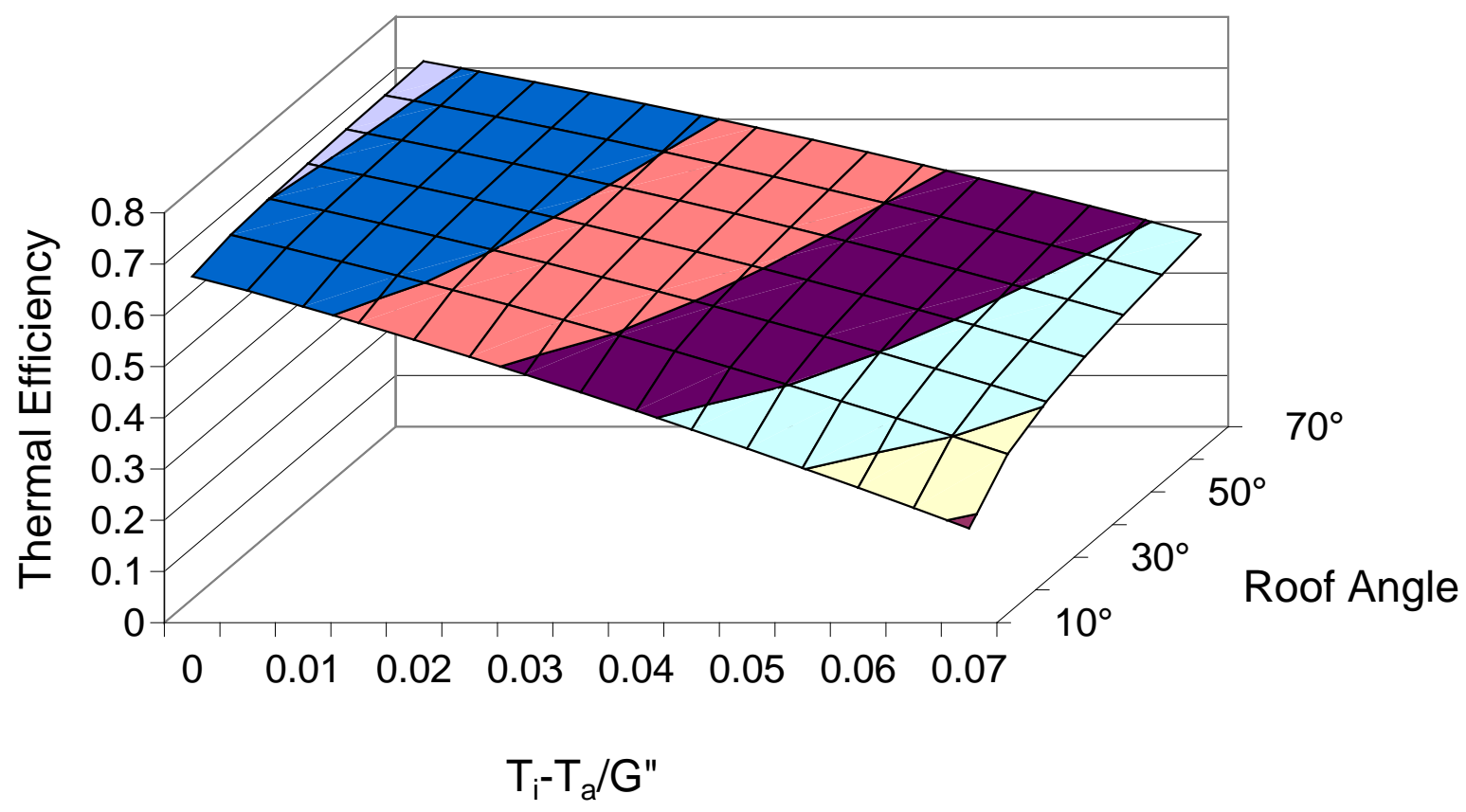

Figure 19: BIPVT thermal efficiency for varying roof inclination 